\section{$N+1 \rightarrow d-$}

$1 N-9 /-C / C$

\title{
Lunar meteorite Queen Alexandra Range 93069 and the iron concentration of the lunar highlands surface
}

\author{
RANDY L. KOROTEV*, BRADLEY L. JOLLIFF AND KAYLYNN M. ROCKOW
}

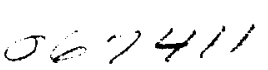

Department of Earth and Planetary Sciences and McDonnell Center for the Space Sciences,

Washington University, St. Louis, Missouri 63130, USA

*Correspondence author's e-mail address: rlk@levee.wustl.edu

\author{
(Received 1995 December 19; accepted in revised form 1996 August 3) \\ (Submitted as part of a series of papers on Queen Alexandra Range 93069 and other lunar meteorites)
}

\begin{abstract}
Lunar meteorite Queen Alexandra Range 93069 is a clast-rich, glassy-matrix regolith breccia of ferroan, highly aluminous bulk composition. It is similar in composition to other feldspathic lunar meteorites but differs in having higher concentrations of siderophile elements and incompatible trace elements. Based on electron microprobe analyses of the fusion crust, glassy matrix, and clasts, and instrumental neutron activation analysis of breccia fragments, QUE 93069 is dominated by nonmare components of ferroan, noriticanorthosite bulk composition. Thin section QUE 93069,31 also contains a large, impact-melted, partially devitrified clast of magnesian, anorthositic-norite composition. The enrichment in $\mathrm{Fe}, \mathrm{Sc}$, and $\mathrm{Cr}$ and lower $\mathrm{Mg} / \mathrm{Fe}$ ratio of lunar meteorites Yamato 791197 and Yamato 82192/3 compared to other feldspathic lunar meteorites can be attributed to a small proportion (5-10\%) of low-Ti mare basalt. It is likely that the nonmare components of Yamato 82192/3 are similar to and occur in similar abundance to those of Yamato 86032 , with which it is paired. There is a significant difference between the average FeO concentration of the lunar highlands surface as inferred from the feldspathic lunar meteorites (mean: $\sim 5.0 \%$; range: $4.3-$ $6.1 \%)$ and a recent estimate based on data from the Clementine mission (3.6\%).
\end{abstract}

\section{INTRODUCTION}

Lunar meteorite QUE 93069, a $21 \mathrm{~g}$ stone, was collected in Antarctica $-45 \mathrm{~km}$ from the collection site of the paired lunar meteorites MAC 88104 and MAC 88105 (hereafter: MAC 88104/5). We report here results of chemical analysis and petrographic examination of QUE 93069 and compare those results with previous results for MAC $88104 / 5$ and other meteorites from the lunar highlands. We also report new data for lunar meteorite Yamato 86032, some of which were presented previously in a figure in Jolliff ef al. (1991).

Of the lunar meteorites recovered so far, about half have highly feldspathic compositions $\left(>25 \% \mathrm{Al}_{2} \mathrm{O}_{3}\right)$ and are thought to represent several random locations in the lunar highlands (e.g., Palme et al., 1991; Warren, 1994). Most contain regolith components and thus appear to represent surface and near surface materials. The low concentrations of incompatible trace elements (ITE) in the feldspathic lunar meteorites compared to highland samples collected by the Apollo missions have been taken to mean that the feldspathic meteorites derive from locations on the Moon distant from the Apollo landing sites (e.g., Pieters et al., 1983; Korotev et al., 1983; Warren and Kallemeyn, 1986; Jolliff et al., 1991; Palme et al., 1991). Thus, their compositions and components have special significance as they tell us about the nature of the lunar highlands far removed from and uncontaminated by mafic, ITE-rich, impact-melt ejecta from the large nearside basins. Compositional differences among the meteorites and between the meteorites and the $\lambda$ pollo samples provide valuable information about regional variations in the lithologies and composition of the lunar surface. This type of information is particularly important now that global, remotely sensed compositional data from the Clementine mission are available, because the feldspathic lunar meteorites provide a degree of "ground truth" for the vast otherwise unsampled regions of the highlands.

In this paper, we examine the causes of some of the compositional differences among the feldspathic lunar meteorites, specifically, the effects of different proportions of ferroan (low $\mathrm{Mg} / \mathrm{Fe}$ ) and magnesian (high $\mathrm{Mg} / \mathrm{Fe}$ ) nonmare components and different proportions of mare-derived components. We also consider the implications of $\mathrm{Fe}$ concentrations in the feldspathic lunar meteorites for estimates (Lucey et al., 1995) of the average surface Fe concentration determined from Clementine data.

\section{SAMPLES STUDIED AND ANALYTICAL PROCEDURES}

For QUE 93069, our study is based on bulk chemical analysis of five 50-70-mg fragments (primary splits $9,10,11,20$, and 21 ; Fig. 1) and petrographic study of a thin section $(93069,31)$. We broke each of the five fragments with an agate mortar and pestle and divided all material from each fragment into two or three subsplits designated A, B, and C. In total, 11 subsplits were prepared, which ranged in mass from 20 to $32 \mathrm{mg}$; ten of these were dominated by one large chip. Results of electron microprobe analysis (EMPA) of glass and minerals in the thin section and instrumental neutron activation analysis (INAA) of the subsplits are presented in Tables $1-7$.

For Yamato 86032 , we received $0.5 \mathrm{~g}$ of material as nine fragments collectively designated Yamato 86032,115 . We broke four of the fragments into smaller chips with an agate mortar and pestle. For INAA, we analyzed 20 subsplits: 14 dark chips that appeared relatively devoid of large clasts (3-11 mg each), 5 chips that were dominated by whitish clastic material (2$7 \mathrm{mg}$ each), and a sample of residual fines $(11 \mathrm{mg}$ ) for a total of $114 \mathrm{mg}$. In Table 8 , column 1 contains the mass-weighted mean concentrations of the clast-poor chips and the residual fines subsplit; the sample standard deviation and minimum and maximum concentrations observed for these 15 subsplits are listed in columns 5,6 , and 7 . Column 2 contains mass-weighted mean concentrations for the five whitish, clast-rich chips, which were al! similar in composition. We prepared fused beads for major element analysis by IMPA of seven of the dark, matrix-rich chips analyzed by INAA and thin sections from three of the remaining large unirradiated fragments $(\Lambda=$ $107 \mathrm{mg}, \mathrm{B}=22 \mathrm{mg}$, and $\mathrm{C}=17 \mathrm{mg}$ ). The average major-element composition of the fused beads is given in Table 9 along with the compositions of a thick glass vein and the glassy breccia matrix taken from thin section A.

All analytical procedures were the same as those described in Jolliff et al. (1991), except that for QUE 93069 the samples received a $24 \mathrm{~h}$ irradiation.

\section{RESULTS}

\section{Petrography of QUE 93069}

Our petrographic description is based primarily on examination of thin section QUE 93069,31 and to a lesser extent on examination by binocular microscope of the chips analyzed by IN $\Lambda$ A. The rock 
(a) ,9

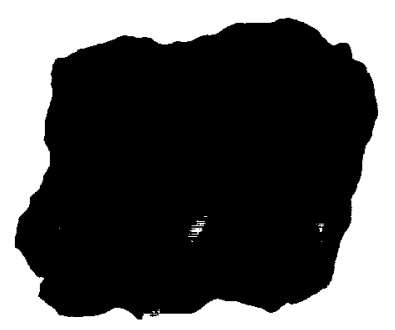

(c), 10

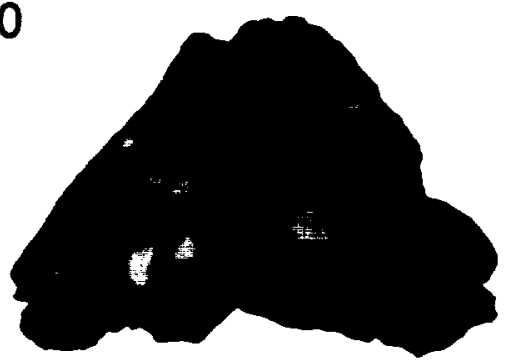

(e) ,11

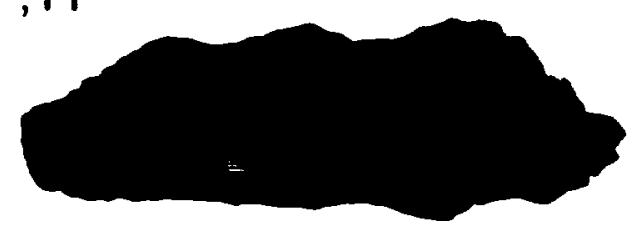

(g) , 20

(i) ,21
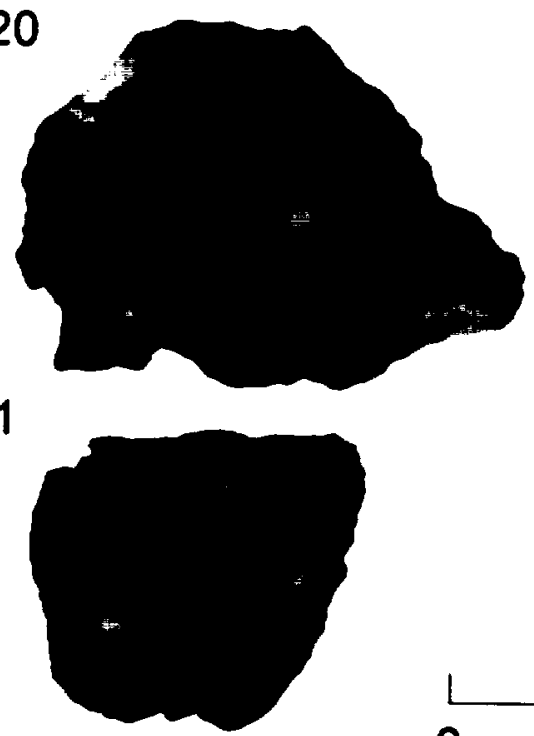

(b) ,9

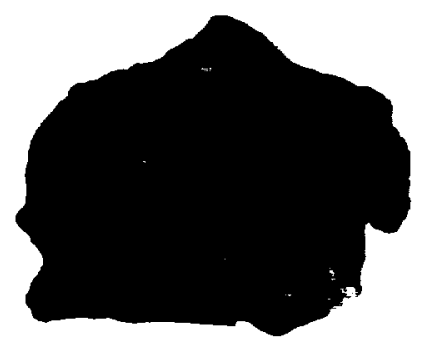

(d) ,10



(f), 11

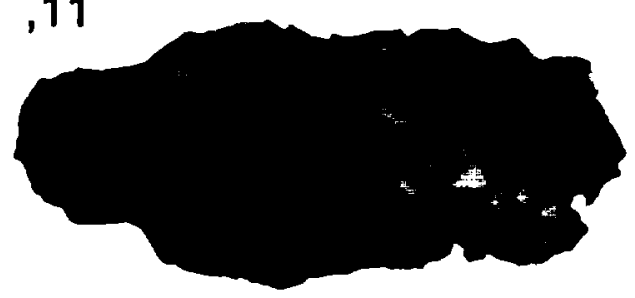

(h) ,20

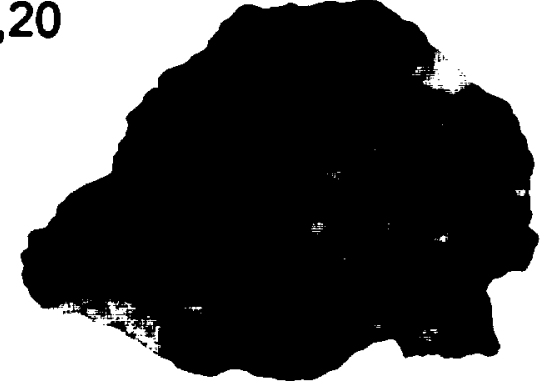

(j) ,21

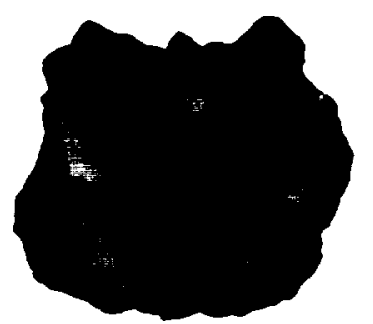

FIG. 1. Photomicrographs of subsplits of QUE 93069 analyzed by INAA. Two photographs are shown for each subsample (e.g, a and b are opposite sides of the same rock chip). Point counts of enlarged versions of these and additional photographs were used to estimate the proportion of clasts greater than $-100 \mu \mathrm{m}$. The results are as follows (clasts:matrix): split 9 (21:79); split 10 (40:60); split 11 (28:72); split $20(31: 69)$; and split 21 (20:80). The average proportions are $28 \%$ clasts and $72 \%$ matrix. These are minimum clast proportions because they neglect clasts smaller than $\sim 100 \mu \mathrm{m}$.

chip in thin section QUE 93069.31 measures $\sim 6 \mathrm{~mm} \times 10 \mathrm{~mm}$ (Fig. 2). About a third of the thin section is highly vesicular, nondevitrified fusion crust. The glass of the fusion crust is optically clear and distinctly separated, along a sharp, smooth contact, from the partially melted rims of the interior rock adjacent to the fusion crust (Fig. 2).
Another third of the thin section is dark brown. glassy-matrix breccia, laden with microscopic clasts (Fig. 3a,b,c). We refer to the matrix as "glassy" even though there is abundant clastic material in the $<20 \mu \mathrm{m}$ size range because even these very tiny grains appear to be welded by glass, albeit a small amount (Fig. 4). The matrix is as 

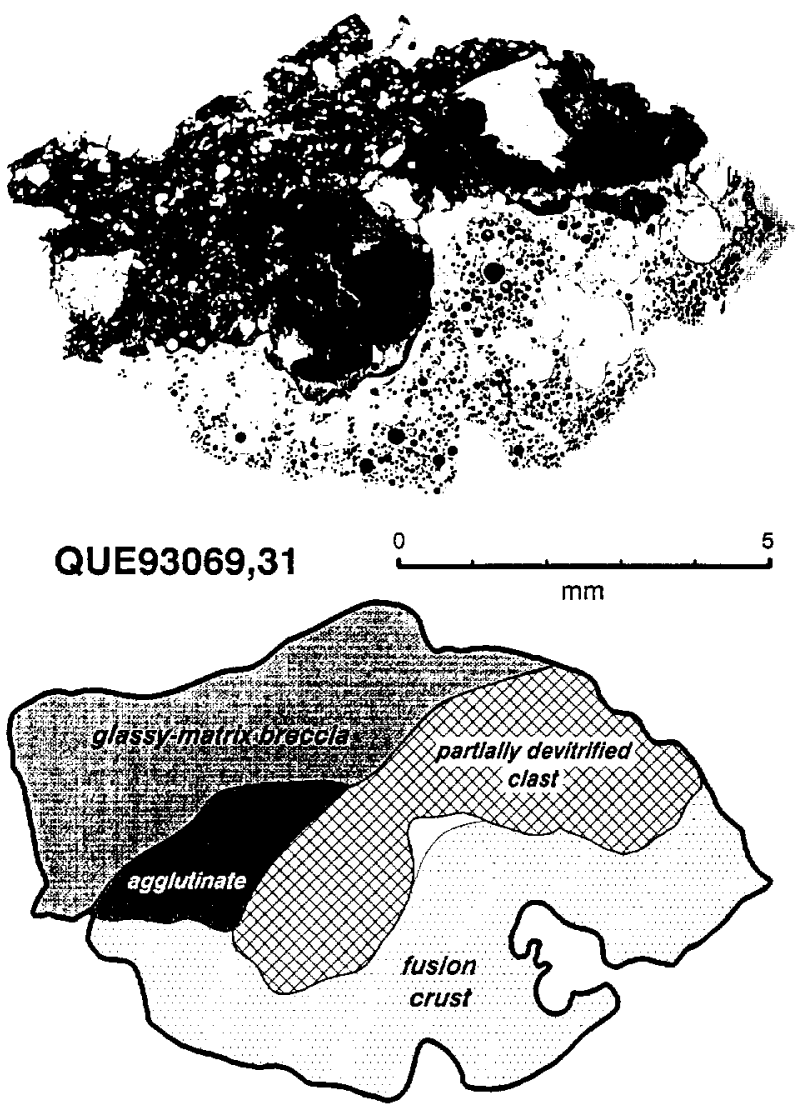

FIG. 2. Transmitted light photomicrograph of QUE 93069,31 under partially crossed polarizers (upper polarizer rotated substantially). The thin section measures $\sim 6 \mathrm{~mm} \times 10 \mathrm{~mm}$. Approximately one-third of the section consists of optically clear, highly vesicular fusion crust (small dark vesicles are not filled with epoxy). Roughly another third is clast-rich, dark-brown, glassy-matrix regolith breccia including a large agglutinate. The final third is a partially quenched or devitrified, brown glassy clast, sandwiched between the fusion crust and glassy-matrix breccia. This large clast partially remelted adjacent to the fusion crust but is in sharp contact with the fusion crust. Along the contact between breccia and fusion crust in the left side of the photo, the clear glass of the fusion crust contacts dark brown, vesicular glass; although the latter may have remelted along this contact, it appears to be part of a large agglutinate.

hard as the clasts it contains (Fig. $3 \mathrm{f}$ ) and it has effectively zero porosity (see also Bischoff, 1996). As a result, the meteorite is coherent and tough, quite unlike most fragmental-matrix regolith breccias but similar to many glassy-matrix regolith breccias in the Apollo samples and similar to other feldspathic lunar meteorites (see also Warren and Kallemeyn, 1995). The clast population of this part of the thin section is dominated by plagioclase and feldspathic lithic clasts and glasses, although the largest mineral clast is an orthopyroxene grain and small pyroxene and olivine clasts are also common. Fragments of glass spheres and irregularly shaped glass fragments are abundant. The glassy matrix contains one $\sim 150 \mu \mathrm{m}$ metal fragment $(\sim 93 \% \mathrm{Fe}, 6.5 \% \mathrm{Ni}, 0.3 \% \mathrm{Co})$ and a few very finegrained, scattered metal blebs. This glassy-matrix breccia lithology probably best represents the bulk of the interior of the meteorite and the chips analyzed by INAA. Point counts of photographs of the chips analyzed by INAA show the meteorite to be a clast-rich breccia consisting of $28 \%$ clasts of several hundred micrometers or larger size (Fig. 1). If smaller clasts were included, the clast abundance would probably exceed $50 \%$.
The final third of the thin section is a $\sim 2 \mathrm{~mm} \times 4 \mathrm{~mm}$ fragment of a single large, impact-melted but partially quenched and devitrified brown clast (Fig. 2). We refer to it throughout the text as the "partially devitrified clast." It is wedged between the brown, glassymatrix breccia and the fusion crust; it has a light-brown, remelted rim adjacent the fusion crust (Figs. 2 and 3 d,e). The clast has two "lobes" (Fig. 3d,e) and consists mostly of weakly variolitic devitrified areas. Several regions of optically clear, nonvesicular glass that are not devitrified occur within the clast. These glassy areas are not entirely in the interior of the clast; they also contact the breccia matrix directly (Fig. 3e,f). The devitrified areas protrude along arcuate fronts into the glassy areas (Fig. 3e). The devitrified areas are strongly fractured, but most of the fractures do not extend into the glassy areas or into the surrounding breccia. The clast contains several $40-60 \mu \mathrm{m}$ blebs of meteoritic metal $(\sim 83 \% \mathrm{Fe}, 10 \% \mathrm{Ni}$, $0.5 \% \mathrm{Co}$, with variable concentrations of $\mathrm{P}$, and in some cases $\mathrm{S})$. In detail, these blebs are very fine grains of metal intergrown with, or surrounded by, a phosphide matrix and troilite. The relatively high $P$ concentration of the metal grains is consistent with their having cooled rapidly (quenched) from high temperature impact melt (Gooley et al., 1973). It appears as though the clast was a glass and probably devitrified or quenched prior to its incorporation into the regolith breccia (it is not an agglutinate). Partial remelting of the clast occurred along the exterior surface adjacent to the fusion crust, but this melt remained separate and did not mix with the fusion crust (see below).

\section{Bulk Composition of QUE 93069}

The fusion crust of QUE 93069 is homogeneous in composition and has essentially the same composition as the brown, glassy matrix of the breccia (Table 1). Concentrations of $\mathrm{FeO}$ and $\mathrm{CaO}$ in the "whole-rock" breccia chips analyzed by INAA (Table 2, Fig. 5) are nearly the same as for the fusion crust, and the composition of the fusion crust agrees well with the bulk composition of the meteorite determined by x-ray fluorescence spectroscopy (Spettel et al., 1995); thus the composition obtained here for the fusion crust reasonably approximates the bulk composition of the meteorite. If the composition of the fusion crust is equivalent to the bulk composition of the meteorite, then the compositional similarity of the glassy breccia matrix to the fusion crust means that the clast assemblage must have about the same composition (i.e., a composition equivalent to $\sim 80 \%$ normative plagioclase).

Lunar meteorite QUE 93069 is generally similar to other meteorites from the lunar highlands in being rich in $\mathrm{Al}\left(29 \%\right.$ as $\left.\mathrm{Al}_{2} \mathrm{O}_{3}\right)$ and having low concentrations of incompatible trace elements (Table 2) compared to feldspathic regoliths from Apollos 15, 16, and 17 The meteorite is distinct in being at the high-Al, low-Fe end of the observed compositional range of feldspathic lunar meteorites (Fig. 6). Consistent with the high $\mathrm{Al}$ concentration, average concentrations of Sc and $\mathrm{Cr}$ are slightly lower in QUE 93069 than in any of the other lunar meteorites (e.g., Fig. 7b). These observations plus the low $\mathrm{TiO}_{2}$ concentration $(0.24 \%)$ and low $\mathrm{Ca} / \mathrm{Al}$ ratio (normative orthopyroxene > clinopyroxene, Table 1) suggest that QUE 93069 has at most a minor mare component. The most significant differences between QUE 93069 and the other feldspathic lunar meteorites are that QUE 93069 has greater concentrations of both incompatible trace elements (Fig. 7a) and siderophile elements (Fig. 8)

Overall, QUE 93069 is most similar in composition to $\mathrm{MAC}$ 88104 and MAC 88105 (Figs. 6, 7, and 9), although it is not as similar as the paired MAC stones are to each other. Major-element concen- 


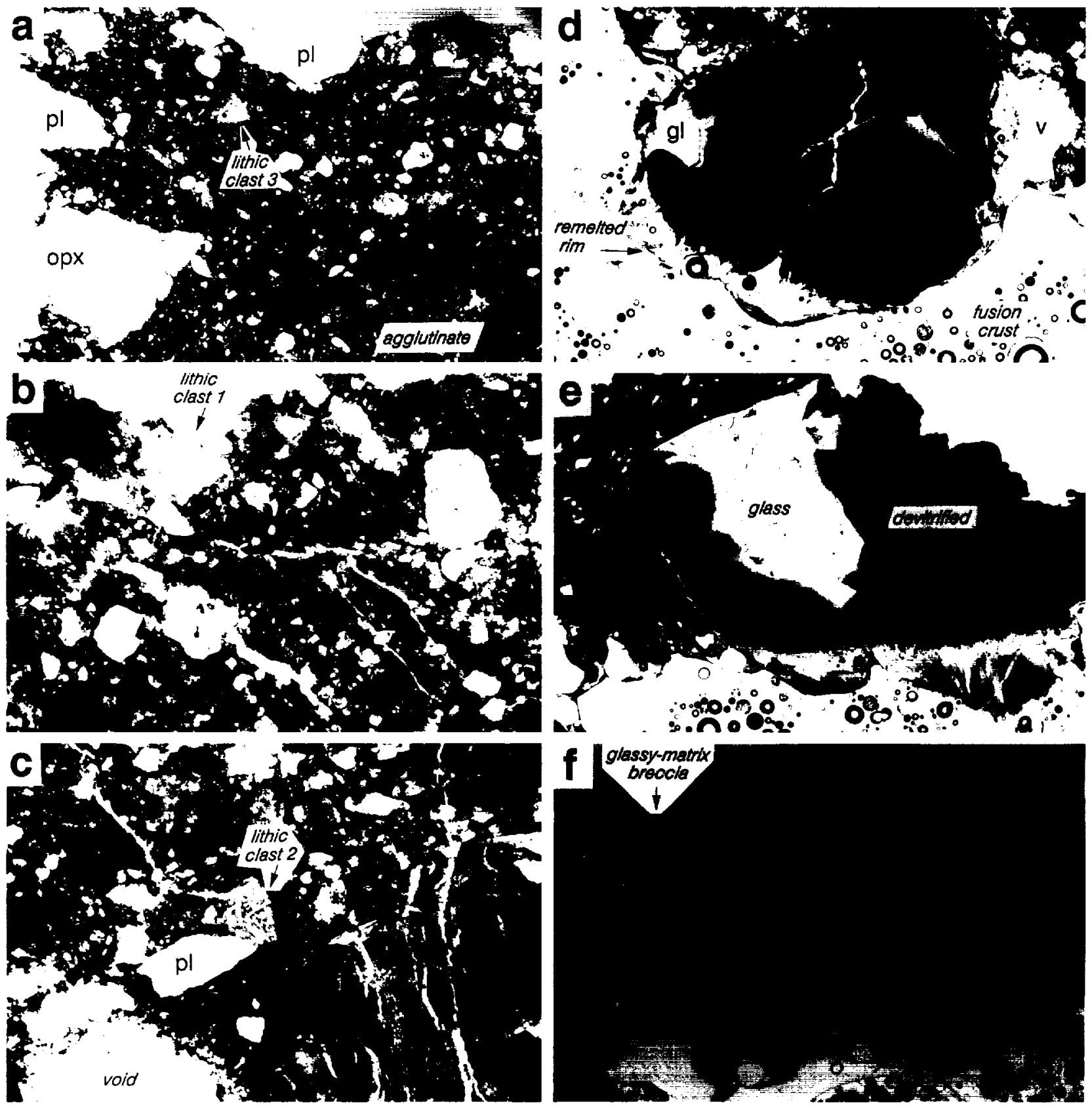

FIG. 3. Photomicrographs of parts of QUE 93069,31 . (a) Clast-rich, brown, glassy-matrix breccia in transmitted light, under partially crossed polarizers (upper polarizer rotated slightly). Field of view is $-3.3 \mathrm{~mm}$ and is an enlargement of the upper-left part of Fig. 2. Most of the bright clasts are plagioclase grains ( $\mathrm{pl}$ ), although the largest one, in the lower left, is orthopyroxene (Table 4, Px 1). Other clasts include small polygranular lithic clasts $(e$., lithic clast 3) and glass fragments (glasses are light gray, similar in shade to the epoxy). Part of large agglutinate is visible in lower right (cf., lig. 2). (b) Clast-rich, brown glassy-matrix breccia in transmitted light, $\sim 1.6 \mathrm{~mm}$ across. Black mass at upper left is Fe-Ni-Co metal. Lithic clasts are small and fine grained, such as the one to the right of the metal (lithic clast 1 , Table 7) and in the upper right quadrant. Just below the latter is a clast of about three-fourths of a glass spherule (glass clast 12, Table 6). (c) Clast-rich, glassy-matrix breccia and part of the large, partially devitrified clast (lower-right quadrant) from the upper, central area of Fig. 2. Field of view is $1.6 \mathrm{~mm}$, transmitted light. A small, intergranular-textured lithic clast (lithic clast 2, Table 7) occurs in the center of the photo. (d) Part of the partially devitrified, brown glass clast (near center of Fig. 2). The fusion crust has abundant vesicles, is optically clear and contacts sharply the partially remelted rim of the clast. Thin, wispy schlieren are visible along the edge of the remelted rim. The clear area in the upper left part of the partially devitrified clast is glass (gl) and the clear area along the right side is a large void (v) filled with epoxy. Field of view is $3.3 \mathrm{~mm}$, transmitted light. (c) Partially devitrified, brown glass clast with fusion crust along the lower edge and glassy-matrix breccia along the upper left. The center of the large clast is optically clear glass of identical composition to the devitrified areas and the remelted rim (schlieren-bearing zone). Ficld of view is 3.3 mm, 1 ransmitted light. (f) This image is nearly the same area as (e), but in combined reflected and transmitted light. The devitrified area is strongly fractured, possibly as a consequence of its devitrification. Field of view is $3.3 \mathrm{~mm}$. 


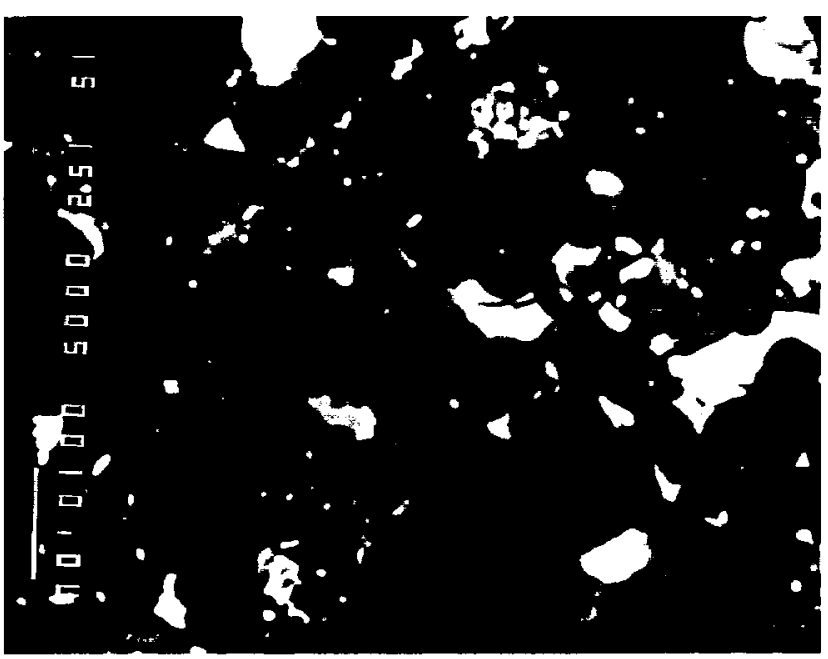

FIG. 4. Backscattered-electron image of matrix in the glassy-matrix breccia. The darkest grains are mainly plagioclase, and the bright grains are pyroxene, olivine, ilmenite, troilite. and metal. The gray material of intermediate brightness, heterogeneous on a very small scale, and surrounding all clasts is glass. The scale bar is $10 \mu \mathrm{m}$ and the image is $-70 \mu \mathrm{m}$ across.

trations determined by LMPA are very similar for MAC $88104 / 5$ and the fusion crust of QUE 93069 (Table 1), except that the $\mathrm{Mg}$ concentration of QUE 93069 is $1.16 \times$ greater, leading to a slightly greater value of $\mathrm{Mg}^{\prime}$ (bulk mole percent $\left.\mathrm{Mg} / \mathrm{Mg}+\mathrm{Fe}\right]$ ) in QUE 93069 (65 vs. 62; Fig. 9). Based on INAA data for subsplits, differences between mean concentrations in QUE 93069 and MAC 88104/5 for some elements associated with major mineral phases $(\mathrm{Ca}, \mathrm{Sc}, \mathrm{Cr}$, $\mathrm{Fe}$ ) are $<7 \%$ and not statistically significant ( $t$-test at $95 \%$ confidence level, based on 11 subsplits of QUE 93069 and 17 subsplits of MAC 88104/5; Jolliff et al, 1991). However, several trace elements are in significantly greater concentration in QUE 93069: Na (1.04x), Fu $(1.07 \times)$, incompatible trace elements $(1.3-1.4 \times)$, and $\mathrm{Ni}$, $\mathrm{Au}$, and $\operatorname{Ir}(-2 x)$.

\section{QUE93069 glasses and bulk sample splits}

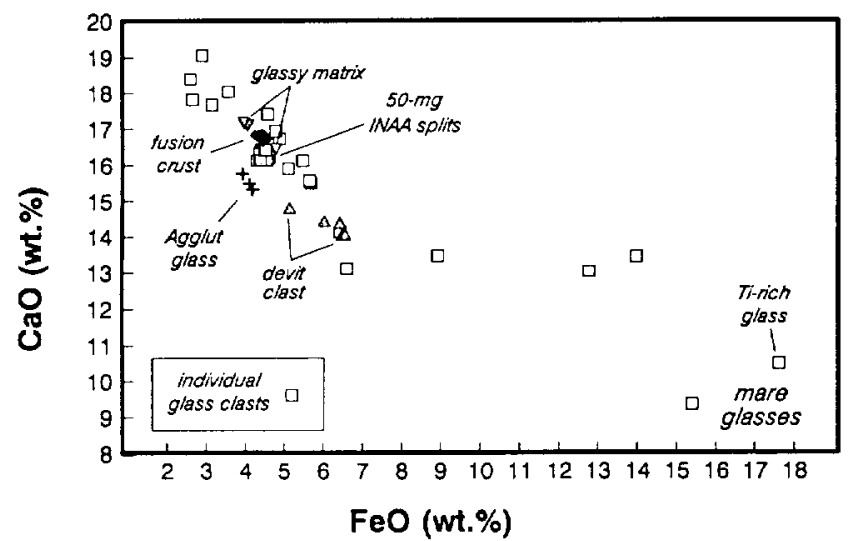

Fig. 5. Concentrations of ( $\mathrm{CO}$ vs. FeO in bulk subsample splits and in glasses in QUE 93069. Compositions of INAA splits (stippled squares) are given in Table 2. Analyses of the fusion crust (diamonds) and "glassy matrix" (downward triangles) were made by electron microprobe using a $20-40 \mu \mathrm{m}$ broad beam (Table 1). Analyses labeled "Agglut glass" $(+)$ are broad-beam analyses (Table 6, last column) of glassy matrix in a large clast that we infer to be an agglutinate. Analyses labeled "devit clast" (upward triangles) are individual broad-beam analyses of the large, partially devitrified clast (Table 1). Most of the glass clast compositions (open squares) cluster near the bulk composition. The Ti-rich glass contains $\sim 9 \% \mathrm{TiO}_{2}$ (Table 6).
TABLE 1. Major-element composition and modified mineral norm of the main components in thin section QUE 93069,31 and comparison to MAC $88104 / 5$

\begin{tabular}{|c|c|c|c|c|c|c|c|}
\hline & \multirow{3}{*}{$\frac{\text { MAC* }}{\text { fused }}$} & \multicolumn{6}{|c|}{ QUE 93069,31} \\
\hline & & \multicolumn{2}{|c|}{ fusion crust } & \multicolumn{2}{|c|}{$\begin{array}{l}\text { brown glass } \\
\text { matrix }\end{array}$} & \multicolumn{2}{|c|}{$\begin{array}{l}\text { partially de- } \\
\text { vitrified clast }\end{array}$} \\
\hline & & mean & $s$ & mean & $s$ & mean & $s$ \\
\hline \multicolumn{8}{|c|}{ major-element composition } \\
\hline $\mathrm{SiO}_{2}$ & 45.3 & 44.2 & 0.2 & 44.6 & 0.7 & 46.2 & 0.5 \\
\hline $\mathrm{TiO}_{2}$ & 0.24 & 0.24 & 0.01 & 0.21 & 0.05 & 0.35 & 0.02 \\
\hline $\mathrm{Al}_{2} \mathrm{O}_{3}$ & 29.0 & 29.0 & 0.2 & 29.7 & 1.5 & 24.0 & 0.9 \\
\hline $\mathrm{Cr}_{2} \mathrm{O}_{3}$ & 0.09 & 0.07 & 0.02 & 0.07 & 0.01 & 0.15 & 0.03 \\
\hline $\mathrm{FeO}$ & 4.32 & 4.38 & 0.07 & 4.28 & 0.45 & 6.10 & 0.59 \\
\hline $\mathrm{MnO}$ & 0.06 & 0.07 & 0.03 & 0.06 & 0.01 & 0.08 & 0.02 \\
\hline $\mathrm{MgO}$ & 3.89 & 4.52 & 0.03 & 4.49 & 0.73 & 8.14 & 0.45 \\
\hline $\mathrm{CaO}$ & 16.7 & 16.8 & 0.1 & 16.9 & 0.4 & 14.3 & 0.3 \\
\hline $\mathrm{Na}_{2} \mathrm{O}$ & 0.34 & 0.29 & 0.03 & 0.32 & 0.03 & 0.36 & 0.03 \\
\hline $\mathrm{K}_{2} \tilde{\mathrm{O}}$ & 0.03 & 0.03 & 0.01 & 0.03 & 0.01 & 0.12 & 0.03 \\
\hline $\mathrm{P}_{2} \mathrm{O}_{5}$ & 0.08 & 0.03 & 0.01 & 0.03 & 0.01 & 0.04 & 0.02 \\
\hline Sum & 100.1 & 99.6 & & 100.7 & & 99.8 & \\
\hline$N$ & & 10 & 3 & & & 5 & \\
\hline$M g^{\prime}$ & 61.6 & 64.8 & & 65.2 & & 70.4 & \\
\hline$A n^{\prime}$ & 96.2 & 96.7 & & 96.5 & & 94.4 & \\
\hline \multicolumn{8}{|c|}{ normative mineralogy (modified CIPW norm) } \\
\hline Or & 0.18 & 0.18 & & 0.18 & & 0.71 & \\
\hline $\mathrm{Ab}$ & 2.87 & 2.46 & & 2.69 & & 3.05 & \\
\hline An & 77.5 & 77.8 & & 79.0 & & 63.6 & \\
\hline$\sum \mathrm{Fsp}$ & 80.5 & 80.7 & & 81.8 & & 67.4 & \\
\hline Opx & 12.8 & 7.19 & & 6.91 & & 19.7 & \\
\hline$C p \mathrm{x}$ & 4.11 & 4.45 & & 3.33 & & 5.84 & \\
\hline$\sum \mathrm{Px}$ & 16.9 & 11.6 & & 10.2 & & 25.5 & \\
\hline$\Sigma \mathrm{Ol}$ & 1.75 & 7.06 & & 7.36 & & 0.14 & \\
\hline $\mathrm{llm}$ & 0.46 & 0.46 & & 0.40 & & 0.67 & \\
\hline Chm & 0.13 & 0.10 & & 0.10 & & 0.22 & \\
\hline$A p t$ & 0.19 & 0.07 & & 0.07 & & 0.09 & \\
\hline
\end{tabular}

Values in weight percent. $N=$ number of spots analyzed; $s=$ sample standard deviation. $\mathrm{Mg}^{\prime}=$ molar $\mathrm{MgO} /(\mathrm{MgO}+\mathrm{FeO}) \times 100 . \quad A n^{\prime}=$ normative $A n /(A n+A b+O r) \times 100$. Modified CIPW norm given in weight percent normative minerals.

*MacAlpine Hills $88104 / 5$ bulk composition from Jolliff et al. (1991).

\section{Compositions of Clasts in QUE 93069,31}

The large, partially devitrified clast observed in thin section is uniform in composition, whether measured in the clear. glassy area, in the devitrified areas, or in the partially remelted rim adjacent the fusion crust (Table 1). Compositionally, the partially devitrified clast is more mafic than the fusion crust and the brown. glassy-matrix breccia (Fig. 5) and is somewhat richer in $\mathrm{Mg}$ and $\mathrm{Cr}$, but it still represents a plagioclase-rich protolith (Fig. 10). It has a significantly higher $\mathrm{K}$ concentration and slightly higher $\mathrm{Ti}$ and $\mathrm{P}$ concentrations than the bulk meteorite. With an $\mathrm{Mg}^{\prime}$ value of 70.4 and normative $\mathrm{An}$ content $(\mathrm{An} /[\mathrm{An}+\mathrm{Ab}+\mathrm{Or}] \times 100)$ of 94 , its composition is intermediate to ferroan-anorthositic and magnesian-suite nonmare igneous rocks. The clast has a normative composition corresponding to anorthositic norite, and its composition is similar to ALHA81005 (Kallemeyn and Warren, 1983; Palme et al, 1983: Warren and Kallemeyn, 1991) and some estimates of the average lunar crust (e.g., Taylor, 1975). Although we do not know whether it had one or many lunar-rock precursors, the presence of meteoritic metal suggests a polymict parentage.

Many of the clasts in the glassy-matrix breccia of QUE, 93069,31 are either single minerals or individual glass fragments; however, lithic clasts also are abundant. From examination of some of the breccia fragments shown in Fig. 1, lithic clasts appear to be even more 
TABLE 2. Results of instrumental neutron activation analysis for subsplits of QUE 93069

\begin{tabular}{|c|c|c|c|c|c|c|c|c|c|c|c|c|c|c|}
\hline &, $9 \Lambda$ & $.9 \mathrm{~B}$ & $.10 \mathrm{~A}$ & $.10 \mathrm{~B}$ & $.10 \mathrm{C}$ &, $11 \Lambda$ &, $11 \mathrm{~B}$ & $20 \mathrm{~A}$ &, $20 \mathrm{~B}$ &, $21 \mathrm{~A}$ & ,2 I B & $\theta$ & $s$ & $\begin{array}{l}\text { mass } \\
\text { wi'd. } \\
\text { mean }\end{array}$ \\
\hline $\mathrm{Na}_{2} \mathrm{O}$ & 0.352 & 0.353 & 0.356 & 0.355 & 0.356 & 0.351 & 0.353 & 0.354 & 0.357 & 0.355 & $0.36 \mathrm{I}$ & 0.004 & 0.003 & 0.355 \\
\hline $\mathrm{CaO}$ & 16.2 & 16.2 & 16.4 & 16.2 & 16.4 & 16.1 & 16.4 & 16.3 & 16.1 & 16.1 & 16.4 & 0.3 & 0.1 & 16.3 \\
\hline $\mathrm{Sc}$ & 7.96 & 7.97 & 7.77 & 8.25 & 7.67 & 7.33 & 7.64 & 7.49 & 7.90 & 7.57 & 7.88 & 0.08 & 0.26 & 7.75 \\
\hline $\mathrm{Cr}$ & 645 & 652 & 599 & 597 & 574 & 568 & 607 & 595 & 606 & 571 & 617 & 6 & 28 & 603 \\
\hline $\mathrm{FeO}_{\mathrm{t}}$ & 4.56 & 4.67 & 4.48 & 4.59 & 4.38 & 4.26 & 4.45 & 4.35 & 4.53 & 4.37 & 4.49 & 0.04 & 0.12 & 4.46 \\
\hline $\mathrm{Cn}$ & 22.5 & 23.0 & 22.8 & 20.7 & 18.5 & 22.5 & 23.4 & 21.5 & 21.6 & 22.3 & 22.2 & 0.2 & 1.4 & 22.0 \\
\hline $\mathrm{Ni}$ & 294 & 306 & 311 & 274 & 226 & 311 & 335 & 279 & 266 & 314 & 296 & 10 & 30 & 295 \\
\hline $\mathrm{Rh}$ & 2.2 & 1.3 & 2.5 & 2.1 & 1.2 & 1.5 & 1.7 & 1.8 & 1.9 & 1.0 & 1.1 & 0.8 & 0.5 & 1.6 \\
\hline $\mathrm{Sr}$ & 160 & 161 & 154 & 143 & 162 & 156 & 161 & 157 & 160 & 162 & 157 & 10 & 6 & 158 \\
\hline $\mathrm{Zr}$ & 46 & 46 & 45 & 47 & 42 & 43 & 51 & 52 & 57 & 40 & 40 & 8 & 5 & 46 \\
\hline $\mathrm{Cs}$ & 0.032 & 0.043 & 0.070 & 0.000 & 0.040 & 0.035 & 0.039 & 0.038 & 0.020 & 0.037 & 0.049 & 0.016 & 0.017 & 0.038 \\
\hline $\mathrm{Ba}$ & 39 & 46 & 48 & 40 & 33 & 40 & 40 & 43 & 47 & 37 & 44 & 4 & 5 & 41 \\
\hline $\mathrm{La}$ & 3.13 & 4.31 & 3.24 & 3.27 & 2.64 & 3.17 & 3.25 & 3.57 & 3.67 & 3.17 & 3.30 & 0.03 & 0.41 & 3.35 \\
\hline $\mathrm{Ce}$ & 8.07 & 11.32 & 8.37 & 8.60 & 6.94 & 8.16 & 8.36 & 9.36 & 9.79 & 8.24 & 8.50 & 0.10 & 1.13 & 8.73 \\
\hline $\mathrm{Nd}$ & 4.9 & 6.9 & 4.6 & 5.0 & 4.3 & 5.1 & 5.3 & 5.5 & 4.9 & 5.5 & 5.5 & 0.8 & 0.7 & 5.3 \\
\hline Sm & 1.519 & 2.120 & 1.556 & 1.599 & 1.266 & 1.525 & 1.558 & 1.743 & 1.771 & 1.538 & 1.582 & 0.016 & 0.212 & 1.623 \\
\hline Eu & 0.832 & 0.835 & 0.841 & 0.819 & 0.814 & 0.818 & 0.828 & 0.834 & 0.847 & 0.822 & 0.835 & 0.010 & 0.010 & 0.830 \\
\hline $\mathrm{Th}$ & 0.301 & 0.409 & 0.332 & 0.332 & 0.254 & 0.295 & 0.310 & 0.348 & 0.371 & 0.311 & 0.316 & 0.008 & 0.038 & 0.326 \\
\hline $\mathrm{Yb}$ & 1.167 & 1.385 & 1.188 & 1.248 & 0.995 & 1.143 & 1.187 & 1.290 & 1.326 & 1.163 & 1.214 & 0.012 & 0.104 & 1.212 \\
\hline Lu & 0.162 & 0.188 & 0.169 & 0.178 & 0.142 & 0.160 & 0.164 & 0.179 & 0.187 & 0.162 & 0.171 & 0.003 & 0.013 & 0.169 \\
\hline Hif & 1.15 & 1.19 & 1.15 & 1.28 & 0.93 & 1.12 & 1.16 & 1.25 & 1.37 & 1.13 & 1.17 & 0.02 & 0.11 & 1.17 \\
\hline $\mathrm{Ta}$ & 0.146 & 0.151 & 0.144 & 0.139 & 0.112 & 0.151 & 0.155 & 0.158 & 0.195 & 0.143 & 0.149 & 0.010 & 0.019 & 0.149 \\
\hline Ir & 11.6 & 13.0 & 57.1 & 11.3 & 9.4 & 13.9 & 14.0 & 12.1 & 11.2 & 12.4 & 13.3 & 0.6 & 13.6 & 16.0 \\
\hline$\Lambda u$ & 4.5 & 4.5 & 3.7 & 3.4 & 2.1 & 4.2 & 4.5 & 4.2 & 4.1 & 4.2 & 4.2 & 0.4 & 0.7 & 4.0 \\
\hline Th & 0.52 & 0.58 & 0.50 & 0.51 & 0.40 & 0.50 & 0.53 & 0.59 & 0.55 & 0.52 & 0.51 & 0.02 & 0.05 & 0.52 \\
\hline U & 0.15 & 0.13 & 0.14 & 0.16 & 0.11 & 0.13 & 0.16 & 0.12 & 0.15 & 0.11 & 0.16 & 0.02 & 0.02 & 0.14 \\
\hline mass (mg) & 24.4 & 27.7 & 23.3 & 20.3 & 21.9 & 22.3 & 30.5 & 31.3 & 19.3 & 32.3 & 27.9 & - & - & 281.0 \\
\hline lab id. & 304.62 & 304.63 & 304.57 & 304.58 & 304.59 & 304.53 & 304.54 & 304.55 & 304.56 & 304.60 & 304.61 & - & - & - \\
\hline
\end{tabular}

Concentration units in $\mu \mathrm{g} / \mathrm{g}$, except oxides in $\mathrm{cg} / \mathrm{g}$ (mass percent) and $\mathrm{Ir}$ and $\mathrm{Au}$ in $\mathrm{ng} / \mathrm{g}, \mathrm{FeO}=$ total $\mathrm{Fe}$ as $\mathrm{FeO}$.

$\sigma=$ estimated analytical uncertainty (standard deviation) for a single subsplit; $s=$ sample standard deviation of all subsplits $(N=11)$.

abundant in other subsamples (e.g., QUE 93069,10). Compositions of representative clasts in QUE 93069,31 are given in Tables 3-7 and illustrated in Figs. 5 and 11 . Most of the mineral clasts are plagioclase with An contents of 96 or greater (Table 3). With the notable exception of a highly magnesian $\left(M g^{\prime} \approx 84\right)$, 1-mm orthopyroxene grain, most of the pyroxene clasts are ferroan, with $\mathrm{Mg}^{\prime}$ values ranging from 55 to 64 (Table 4). Some of these are finely exsolved, $\mathrm{Ca}$ rich $\left(\mathrm{W}_{\mathrm{O}_{32}}\right)$ in bulk composition and are similar to some clinopyroxenes seen in breccias from North Ray crater at Apollo 16 (Jolliff and Haskin, 1995), but they are more Fe rich $\left(\mathrm{Mg}^{\prime}\right.$ 50) than typical pyroxenes of pristine ferroan anorthosites ( $c f$, Bersch et al., 1991; McGee, 1993). Assuming that the plagioclase and pyroxene clasts stem from the same lithologic precursors, ferroananorthositic (noritic anorthosite) components probably dominate the region from which the meteorite derived. Olivine, although less abundant than pyroxene, is present as clasts with a broad range of compositions (lable 5). Rare lithic clasts include very fine-grained granulitic breccia (Fig. 3a), fine-grained, intergranular basalt (Fig. $3 \mathrm{c}$ ), and polymineralic fragments too small to assign a rock type (Table 7). A clast with intergranular texture (Table 7, lithic clast 2) has mineral compositions similar to Apollo 15 pigeonite basalt or aluminous, low-Ti basalt (cf., Papike et al, 1991). All clasts are shocked to some degree and characterized by pervasive fracturing and undulose extinction: however, no maskelynite was observed.

Glass clasts are abundant in the glassy-matrix breccia and have a wide range of compositions, from highly aluminous with as little as $2.6 \mathrm{wt} \% \mathrm{FeO}$ to basaltic with as much as $17 \mathrm{wt} \% \mathrm{FeO}$ and $9 \% \mathrm{TiO}_{2}$ (Table 6, Fig. 5; also Warren and Kallemeyn, 1995). Most are aluminous (cf., Warren and Kallemeyn, 1995); about half of those we analyzed have more than $28 \mathrm{wt} \% \mathrm{Al}_{2} \mathrm{O}_{3}$. Among the largest glass fragments, which we targeted in our analyses of thin section QUE 93069,31, only two showed the strong silica depletion found by Warren and Kallemeyn, 1995 (e.g., glass clast 12, Table 6). Warren and Kallemeyn found a much higher proportion of $\mathrm{Si}$ depleted glass; however, they noted a tendency for Si depletion to be most common among the smallest glasses. About a third of the glasses we analyzed appear to have suffered alkali loss and perhans mild silica depletion. Glasses so affected usually plot in the spinel field of the silica-olivine-anorthite pseudoternary phase diagram (Fig. 10). The abundance of such glasses in the breccia may contribute to the slight silica depletion of the bulk composition relative to MAC $88104 / 5$ (Fig. 10).

\section{Yamato 86032}

On average, our INAA data for Yamato 86032,115 (Tables 8 and 9) are similar to previous data, although our split is compositionally more feldspathic than those upon which the mean concentrations of Koeberl et al. (1989) are based (Fig. 7). Because our compositional data are for numerous small chips instead of one or two large fragments, we make two new observations about the meteorite.

First, the five subsplits identified during sample preparation as being dominated by white clastic material are all similar to each other and dissimilar to any reported subsamples of Yamato 86032 in being significantly enriched in $\mathrm{Na}, \mathrm{Sr}$, and Eu (Table 8, Fig. 7a). The white clasts are no more feldspathic than the darker matrix-rich material and, in fact, Fe concentrations are greater and Ca concen- 


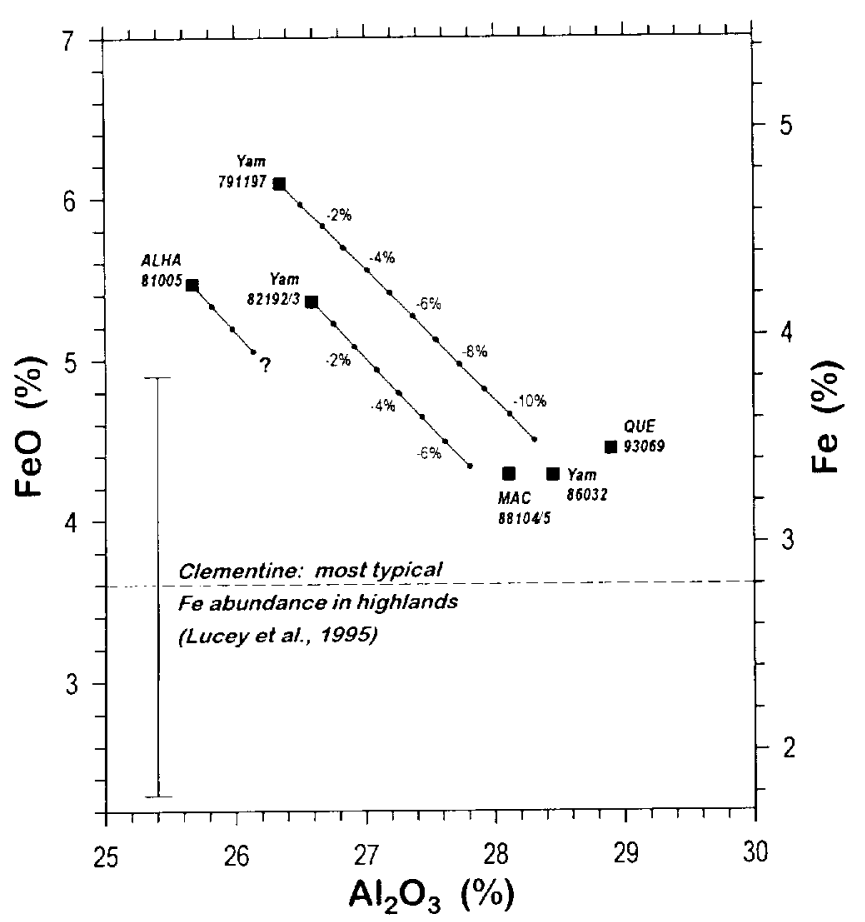

FIG. 6. Concentrations of $\mathrm{Fe}, \mathrm{FeO}$, and $\mathrm{Al}_{2} \mathrm{O}_{3}$ (total element as oxide) in feldspathic lunar meteorites, and comparison to the typical $\mathrm{Fe}$ concentration obtained for the lunar highlands surface by Lucey et al. (1995) from Clementine spectral reflectance data. The error bar along the left edge of the plot represents approximately the width of the peak on Fig. 7 of Lucey et al (1995). Of the three feldspathic lunar meteorites with "high" $(>5 \%)$ $\mathrm{FeO}$ concentrations, there is strong petrographic evidence that Yamato 791197 and Yamato $82192 / 3$ contain a substantial $(5-10 \%)$ component of low-Ti mare basalt and glass (see text). The diagonal lines show the effect of removing mare basalt from the metcorites (assumed basalt composition based on hypothetical low-Ti basalt components of Table 10). Removal of 7\% mare basalt from Yamato $82192 / 3$ (Table 10) and $11 \%$ from Yamato 791197 leaves a residual highlands composition similar to that of the three Fe-poor meteorites. If the lunar meteorites are random samples from the lunar surface, then they suggest that (1) much of the highlands is contaminated by mare-derived material, and (2) it is unlikely that the typical highlands surface actually has as little as $3.6 \% \mathrm{FeO}$, as concluded by Lucey et al (1995). See Fig. 7 for sources of other data.

trations lower in the white clasts (Table 8). The high concentrations of $\mathrm{Na}, \mathrm{Sr}$, and Eu indicate that the white clasts contain plagioclase that is substantially more albitic than that typical of lunar highlands rocks; however, we have not found any corresponding Na-rich clasts in the thin sections we prepared from the other subsplits of the meteorite.

Second, even discounting the white clasts, the subsplits from Yamato 86032 are more compositionally diverse than subsplits from QUE 93069 . For $\mathrm{Ca}$. Fe, $\mathrm{Sc}$, and $\mathrm{Cr}$, relative standard deviations are 4-6 times greater for the 15 "dark" subsplits of Yamato 86032 than for 11 subsplits of QUE 93069 ; for $\mathrm{Na}$, the relative standard deviations is 12 times greater than in QUE, 93069. From the factor of four greater mass of the QUE 93069 subsplits, we would expect that the relative standard deviations for Yamato 86032 would be only about a factor of two greater. Similarly, relative standard deviations for $\mathrm{Na}, \mathrm{Ca}, \mathrm{Fe}, \mathrm{Sc}$, and $\mathrm{Cr}$ are 2 to 4 times greater for the Yamato 86032 subsplits than for subsplits of MAC $88104 / 5$, which were in the same mass range (Jolliff et al, 1991). These observations indicate that the components of Yamato 86032 are not as well mixed, have a greater average grain size, or are more compositionally diverse than those of MAC $88104 / 5$ and QUL 93069
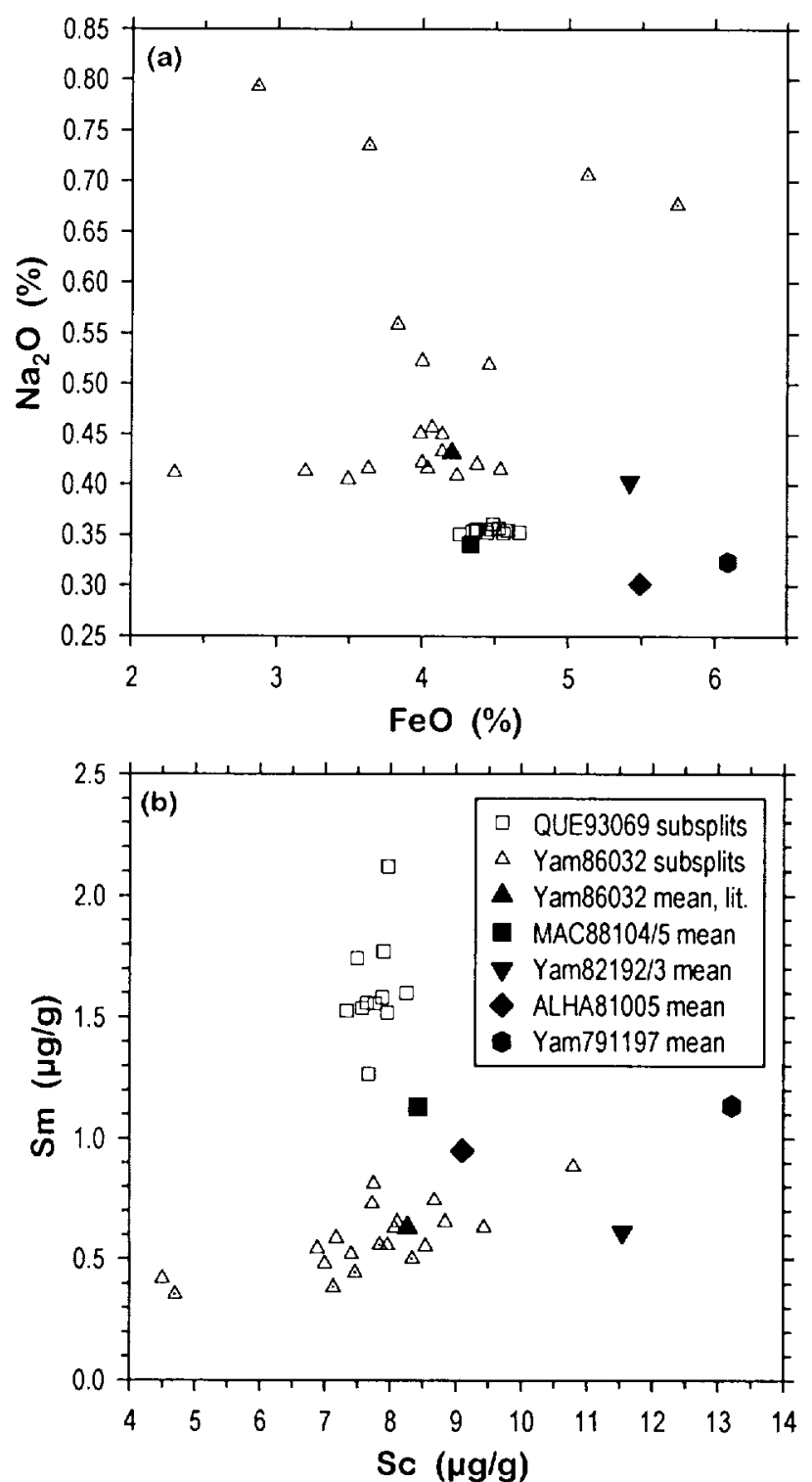

FiG. 7. Concentrations of (a) $\mathrm{Na}_{2} \mathrm{O}$ and $\mathrm{FeO}$ and (b) $\mathrm{Sm}$ and $\mathrm{Sc}$ in subsplits of QUE 93069 and Yamato 86032 (this work) and comparison to mean concentrations in other feldspathic lunar meteorites. The five subsplits of Yamato 86032 that are rich in white clastic material are indicated by dotted triangles. For Yamato 86032, the mean is that of Koeberl et al. (1989); subsplits analyzed here are slightly more feldspathic on average. In this figure and throughout this work, average compositions of lunar meteorites are plotted and discussed. We have calculated these averages from the following sources and other references cited therein: 'Takeda et al (1989). Koeberl et al. (1989, 1990), Jolliff et al. (1991, 1996), Warren and Kallemeyn (1991), Lindstrom et al. (1991), Palme et al (1991), and this work.

\section{DISCUSSION}

\section{Regolith Maturity and Siderophile Elements}

All feldspathic lunar meteorites are polymict breccias from the upper crust of the lunar highlands. Arguably, all are regolith breccias, although Yamato 86032 and Yamato 82192/3, which are compositionally distinct but probably paired (Eugster et al. 1989), are at one extreme in having the lowest abundance of regolith components (glass spheres, agglutinates; Bischoff et al, 1987; Takeda et al, 1987, 1990) and solar wind derived noble gases (Lugster, 1988; 


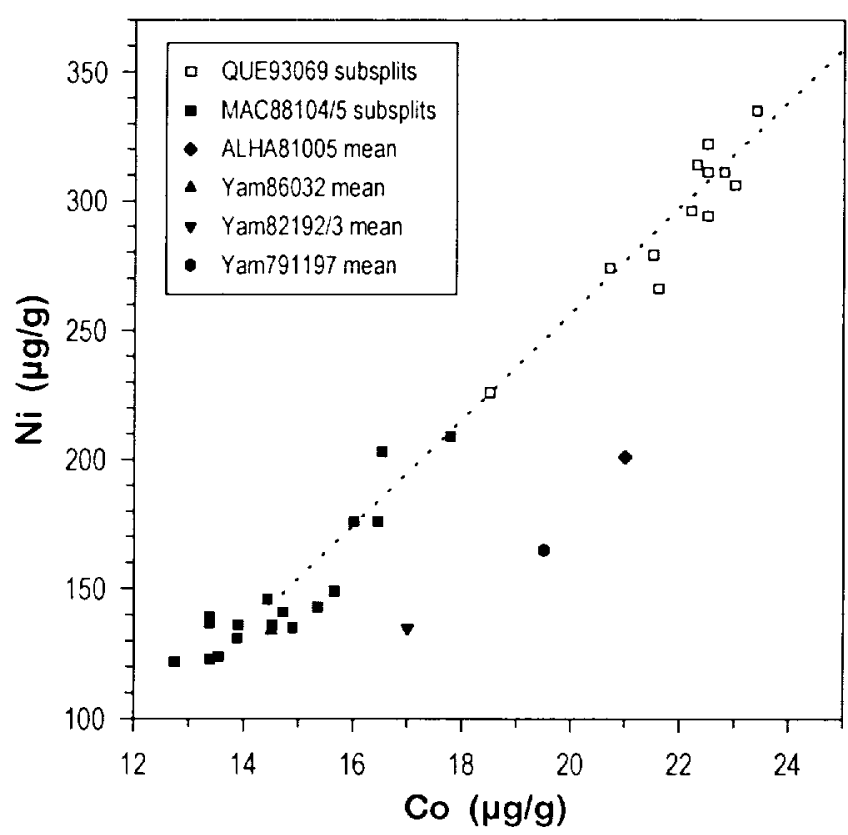

Fig. 8. Concentrations of $\mathrm{Ni}$ and $\mathrm{Co}$ in subsplits of QUE 93069 (this work) and MAC 88104/5 (Jolliff et al., 1991), and comparison to means for other feldspathic lunar meteorites (see Fig. 7 for sources of data). The dotted line represents addition of chondritic (CI) material to the mean composition of the MAC $88104 / 5$

Eugster et al., 1989; Bischoff et al. 1987). Thus, among the regoliths represented by the feldspathic lunar meteorites, that represented by Yamato $82192 / 3 / 86032$ is the least mature, i.e., it has the lowest proportion of components exposed at the lunar surface or it was exposed for a shorter time prior to lithification. In contrast, the regolith represented by QUE 93069 is more mature than that of any other lunar meteorite (lindstrom et al., 1995; Spettel et al., 1995). The compositional data reflect two aspects of this difference in maturity. First, increasing surface exposure leads to a decrease in average grain size and a greater proportion of glass (McKay et al., 1974), which in turn means that small subsamples of a mature regolith are likely to be more compositionally uniform that those from an immature regolith (e.g. Morris et al. 1989: Korotev, 1991), if the regolith is composed of compositionally diverse lithologies. This factor probably contributes in large part to the greater compositional scatter observed among the subsplits of Yamato 86032 compared to QUE: 93069. Sccond, with increasing exposure to micrometeorite influx at the lunar surfiace, siderophile-element concentrations in the regolith increase (e.g. Wasson et al., 1975). Thus, it is no surprise that Yamato 82192/3 and Yamato 86032 have the lowest concentrations of siderophile elements among the feldspathic lunar meteorites and QUI: 93069 has the highest (Fig. 8). Almost certainly, Yamato $82192 / 3 / 86032$ represents a volume of regolith from deeper within the Moon than does QLIE: 93069

In QUI: 93069, the concentrations of $\mathrm{Ni}, \mathrm{Ir}$, and $\mathrm{Au}$ are approximately in chondritic ratios and correspond to $-2.2 \% \mathrm{H}_{2} \mathrm{O}$-free $\mathrm{Cl}$ chondrites (i.e. 1.36 times the CI concentrations of $\Lambda$ nders and Grevesse, 1989). Total siderophile-element abundances in mature Apollo 16 soil are somewhat greater than in QUJE 93069. However, in the Apollo 16 regolith, siderophile elements derive from two sources of subequal importance. About half of the $\mathrm{Ni}, \mathrm{Ir}$, and $\mathrm{Au}$ in the mature Apollo 16 soil is unrelated to maturity because it derives from the rocks of which the soil is in large part composed, the mafic

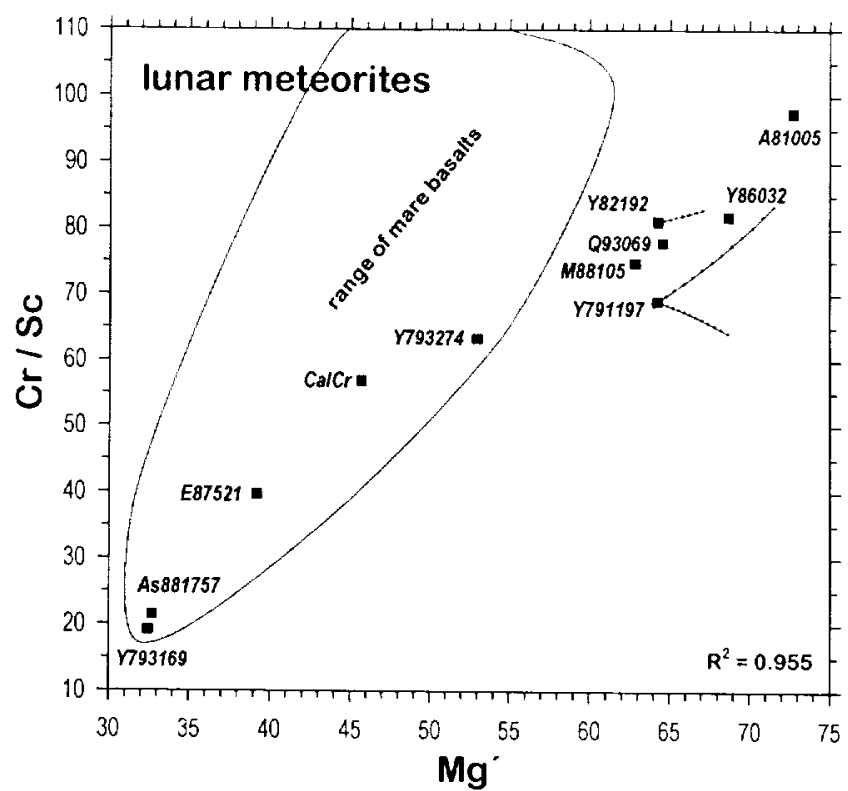

FlG. 9. Among all lunar meteorites, the $\mathrm{Cr} / \mathrm{Sc}$ ratio correlates well with $\mathrm{Mg}$ (bulk mole percent $\mathrm{Mg} /[\mathrm{Mg}+\mathrm{Fe}]$ ). Low-Mg', low-(r/Se meteorites consist primarily of low-Ti mare basalt whereas the high- $M g$ ', high- $\mathrm{Cr} / \mathrm{Sc}$ meteorites consist primarily of feldspathic highlands material. The correlation occurs in part because meteorites plotting toward the center of the distribution are mixtures of mare and highlands material; however, mixing lines are not linear on this plot. Among the feldspathic lunar meteorites, the "low" values of $\mathrm{Mg}^{\prime}$ for Yamato 791197 and Yamato 82192/3 result in part from components of low-Ti mare basalt. The effect of removing the mare components from these two meteorites is shown by the solid curves (see also Fig. 6). For Yamato 82192/3, the curve tracks the removal of un to $7 \%$ lowTi basalt such as that of Table 10. For Yamato 791197, two curves are shown. The lower curve reflects removal of up to $11 \%$ low-Ti basalt such as that of Table $10($ high $(\mathrm{r} / \mathrm{Sc})$; the upper curve shows track of removal of up to $11 \%$ Apollo 14 aluminous (group 5) basalt (low $\mathrm{Cr} / \mathrm{Sc}$; data from Dickinson et al. 1985). Note that the nonmare components (high- $M g^{\prime}$ end of curves) of Yamato 791197 and Yamato 82192/3 have values of $\mathrm{Mg}$ more typical of Yamato 86032 and ALHA81005, making the low $\mathrm{Mg}^{\prime}$ of MAC 88104/5 and QUE 93069, which probably contain $<2 \%$ mare-derived material. even more remarkable. Data from references of lig. 7. Fukuoka (1990), Hill et al. (1991), Warren and Kallemeyn (1993), and Jolliff et al. (1993).

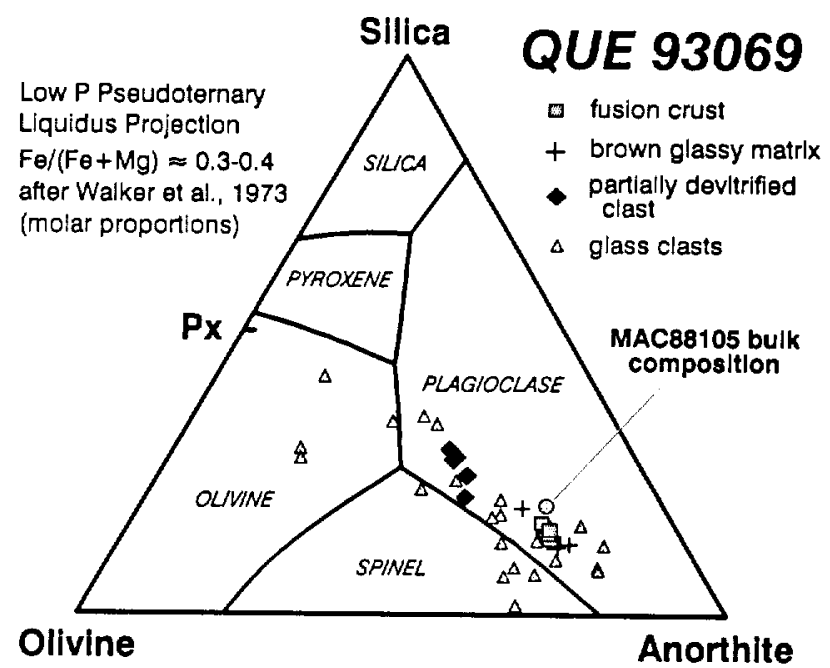

Fig. 10. Pseudoternary plot showing compositions of fusion crust, glass clasts, and glassy matrix of the meteorite measured in thin section (UI: 93069,31 Glasses whose compositions plot away from $\mathrm{SiO}$, and toward the base of the triangle have likely suffered $\mathrm{Si}$ volatilization (cf., Warren and Kallemeyn. 1995). (ilass clast 12 plots below the olivine-plagioclase join. 

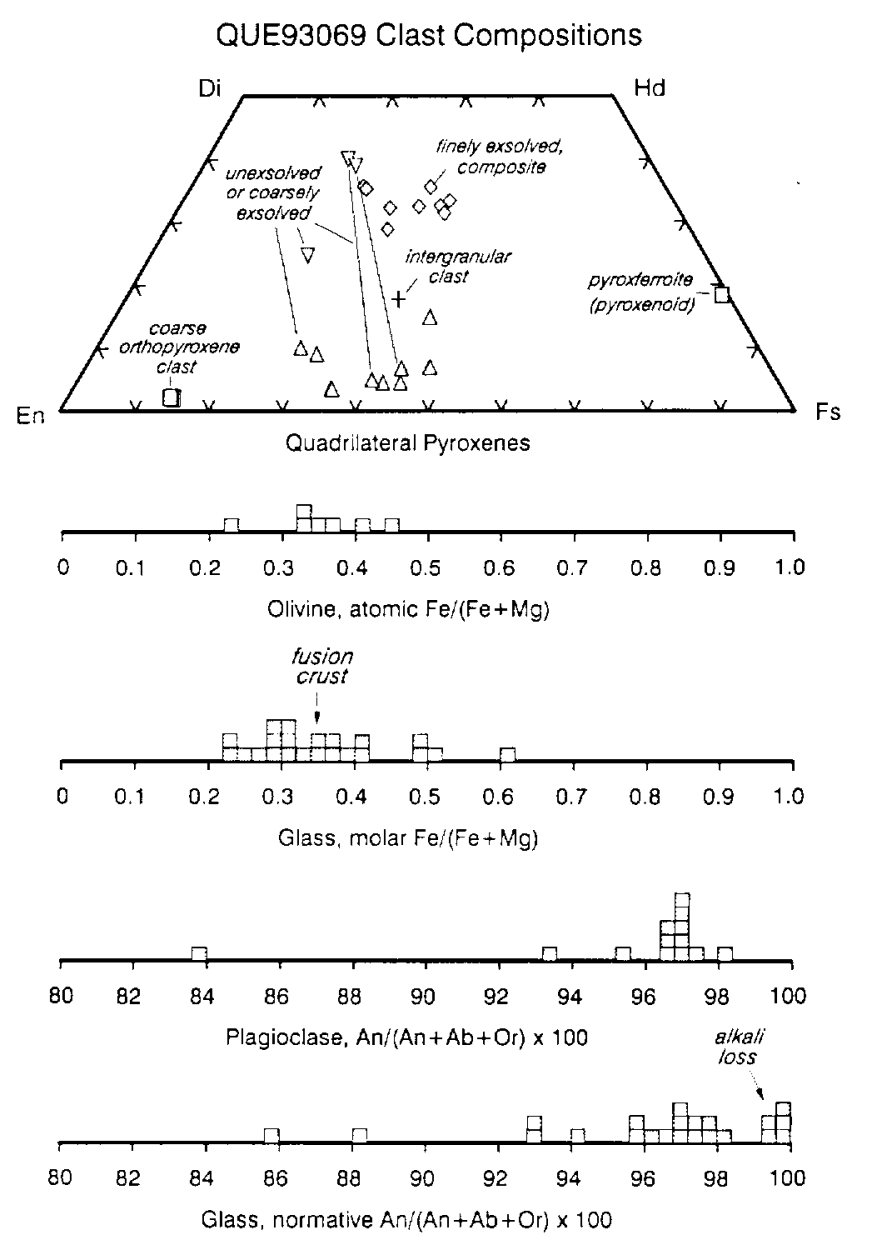

FIG. 11. Pyroxene quadrilatcral and histograms showing molar $\mathrm{Fe} /(\mathrm{Fe}+$ $\mathrm{Mg}$ ) of olivine and glass clasts, and An contents of plagioclase and normative An contents of glass clasts. The molar $\mathrm{Fe} /(\mathrm{Fe}+\mathrm{Mg})$ value of the fusion crust is shown for comparison to the glasses. Glass clasts that have high normative An (99-100) have suffered obvious alkali loss by volatilization during the impact that formed them. We analyzed Na-bearing glass standards under the same operating conditions as the analyses of glasses in QUE 93069 without loss of $\mathrm{Na}$; thus, Na-volatilization did not occur under the electron beam. impact-melt breccias ("VHA" and "LKFM:" Korotev, 1987a). These melt breccias date to the time of basin formation, are rich in $\mathrm{Fe}-\mathrm{Ni}$ metal and incompatible trace elements, and have nonchondritic siderophile-element ratios (Korotev, 1994). Such a component appears to be absent in QUE 93069 . The other half occurs in proportions that are more nearly chondritic and corresponds to about $1-1.5 \%$ water-free Cl chondrites (Wasson et al, 1975; Korotev, 1987a; Korotev, 1996a). This fraction is at the high end of the abundances of meteoritic material found in regoliths from mare areas (e.g. Wasson et al., 1975), most of which derives from micrometeorites and local crater forming impacts. Thus, as a submature regolith (Lindstrom et al., 1995) with the equivalent of $2.2 \%$ water-free $\mathrm{Cl}$ chondrites, QUE 93069 is unusually rich in siderophile elemeríts, suggesting that QUE 93069 represents a near-surface regolith (probably within the top meter or two) and/or that one or more of the source rocks is rich in siderophile elements in chondritic proportions.

\section{Mare Basalt in Yamato 82192/3}

It has been noted that Yamato $82192 / 3$, although paired with Yamato 86032, differs from it in composition in that Yamato 82192/3, on average, is richer in $\mathrm{Fe}, \mathrm{Sc}$, and $\mathrm{Cr}$, poorer in $\mathrm{Al}$ and $\mathrm{Ca}$, and has a significantly lower value of $\mathrm{Mg}^{\prime}, 64 \mathrm{vs} .69$ (Kocberl et al, 1989; Lindstrom et al., 1991; Palme et al., 1991). Several clasts of low-Ti mare basalt have been observed in Yamato 82192/3 (Bischoff $e t$ al., 1987; Gondrich and Keil, 1987) whereas none have been reported from Yamato 86032 (Takeda et al, 1989: Koeberl et al. 1990). As a result, Yamato 82192/3 is compositionally heterogeneous and some subsamples (e.g., those of Warren and Kallemeyn, 1991; Fukuoka et al, 1986; Bischoff et al, 1987; Koeberl, 1988) are substantially more mafic than any subsamples of Yamato 86032. Palme et al (1991) showed that a mixture of $90 \%$ Yamato 86032 and $10 \%$ low-Ti basalt represented by $\Lambda$ pollo 15 sample 15495 provided a reasonable match to the composition of Yamato 82192 for 10 elements. In Table 10, we show (using means of all available analyses) that a close match to all eritical elements can be obtained if hexibility is allowed in the composition of the low-Ti basalt component. Specilically, the composition of Yamato $82192 / 3$ corresponds well to a mixture of $93 \%$ Yamato 86032 and $7 \%$ low-Ti basalt. This modeling exercise is somewhat unconstrained in that the composition of the low-Ti mare basalt component(s) in Yamato 82192/3 is not known and we fabricated the composition of the hypothetical basalt of Table 10 to provide a good lit. However, the hypothetical composition is well within the range of compositions observed among low-Ti mare basalt (e.g., Taylor et al., 1991). These analyses demonstrate that

TABLS: 3. Compositions of plagioclase clasts in QUE $93069,31$.

\begin{tabular}{|c|c|c|c|c|c|c|c|c|c|}
\hline & Plag I & Plag 2 & Plag 3 & Plag 4 & Plag 5 & Plag 6 & Plag 7 & Plag 8 & Plag I I \\
\hline $\mathrm{SiO}_{2}$ & 43.0 & 46.4 & 44.0 & 44.7 & 43.6 & 43.5 & 44.2 & 43.4 & 43.0 \\
\hline $\mathrm{Al}_{2} \mathrm{O}_{3}$ & 35.5 & 33.3 & 36.3 & 36.0 & 36.2 & 35.5 & 34.7 & 35.8 & 35.8 \\
\hline 100 & 0.11 & 0.14 & 0.08 & 0.14 & 0.13 & 0.21 & 0.22 & 0.13 & 0.09 \\
\hline $\mathrm{MgO}$ & 0.10 & 0.01 & 0.12 & 0.06 & 0.08 & 0.16 & 0.02 & 0.07 & 0.05 \\
\hline $\mathrm{CaO}$ & 19.6 & 16.8 & 19.6 & 19.5 & 19.5 & 19.0 & 18.3 & 19.3 & 19.6 \\
\hline $\mathrm{Na}_{2} \mathrm{O}$ & 0.28 & 1.83 & 0.32 & 0.37 & 0.34 & 0.31 & 0.65 & 0.49 & 0.19 \\
\hline $\mathrm{K}_{2} \mathrm{O}$ & $<0.02$ & 0.07 & $<0.02$ & 0.02 & 0.04 & $<0.02$ & 0.07 & $<0.02$ & $<0.02$ \\
\hline Sum & 98.6 & 98.6 & 100.4 & 100.9 & 99.9 & 98.7 & 98.1 & 99.2 & 98.7 \\
\hline \multicolumn{10}{|c|}{ Molecular proportions of anorthite $(A n)$, albite $(\lambda b)$, and orthoclase $\left(\mathrm{Or}_{\mathrm{r}}\right)$} \\
\hline$A n$ & 97.4 & 83.2 & 97.1 & 96.6 & 96.7 & 97.1 & 93.5 & 95.6 & 98.2 \\
\hline $\mathrm{Ab}$ & 2.5 & 16.4 & 2.8 & 3.3 & 3.0 & 2.9 & 6.0 & 4.4 & 1.7 \\
\hline Or & 0.0 & 0.4 & 0.0 & 0.1 & 0.2 & 0.1 & 0.4 & 0.1 & 0.1 \\
\hline
\end{tabular}


TABLE 4. Compositions of pyroxene clasts in QUE93069,31.

\begin{tabular}{|c|c|c|c|c|c|c|c|c|c|c|c|c|c|c|c|}
\hline & \multicolumn{6}{|c|}{ Low-Ca Pyroxene } & \multicolumn{8}{|c|}{ High-Ca Pyroxene } & \multirow{2}{*}{$\begin{array}{l}\text { Pyrox- } \\
\text { ferroite }\end{array}$} \\
\hline & Px 1 & Px 12 & $\operatorname{Px} 2$ & $\operatorname{Px} 9 \mathbf{a}$ & Px 8a & Px 10 & $P \times 9 b$ & Px 8b & Px 13 & $\mathrm{Px} 7$ & Px 5 & $\operatorname{Px} 3$ & Px 6 & Px 4 & \\
\hline $\mathrm{SiO}_{2}$ & 54.9 & 52.7 & 51.9 & 51.4 & 51.0 & 51.6 & 50.8 & 51.0 & 51.0 & 51.3 & 51.2 & 50.1 & 50.3 & 49.2 & 45.5 \\
\hline $\mathrm{TiO}_{2}$ & 0.20 & 0.42 & 0.70 & 0.46 & 0.27 & 0.24 & 1.17 & 0.58 & 0.77 & 0.47 & 0.93 & 1.12 & 1.00 & 0.93 & 0.35 \\
\hline $\mathrm{Al}_{2} \mathrm{O}_{3}$ & 1.60 & 0.57 & 0.60 & 0.56 & 0.53 & 0.24 & 1.99 & 1.43 & 1.59 & 0.99 & 1.23 & 1.35 & 1.20 & 1.50 & 0.29 \\
\hline $\mathrm{Cr}_{2} \mathrm{O}_{3}$ & 0.70 & 0.33 & 0.28 & 0.18 & 0.25 & 0.13 & 0.51 & 0.49 & 0.47 & 0.40 & 0.31 & 0.44 & 0.43 & 0.45 & 0.03 \\
\hline $\mathrm{FeO}$ & 9.35 & 17.8 & 21.7 & 24.9 & 27.3 & 29.0 & 11.3 & 12.3 & 13.9 & 18.3 & 17.2 & 19.7 & 21.0 & 20.7 & 44.4 \\
\hline $\mathrm{MnO}$ & 0.17 & 0.35 & 0.41 & 0.43 & 0.39 & 0.57 & 0.19 & 0.27 & 0.27 & 0.33 & 0.30 & 0.33 & 0.35 & 0.26 & 0.59 \\
\hline $\mathrm{MgO}$ & 30.9 & 22.0 & 21.2 & 19.2 & 17.8 & 16.0 & 13.6 & 13.5 & 13.5 & 14.0 & 13.0 & 10.4 & 10.3 & 9.7 & $<0.02$ \\
\hline $\mathrm{CaO}$ & 1.08 & 4.40 & 1.71 & 2.33 & 2.16 & 2.66 & 20.2 & 19.5 & 17.9 & 14.4 & 15.9 & 16.7 & 15.5 & 16.0 & 7.23 \\
\hline $\mathrm{Na}_{2} \mathrm{O}$ & $<0.03$ & 0.03 & 0.07 & $<0.03$ & $<0.03$ & $<0.03$ & 0.03 & 0.10 & 0.03 & 0.05 & 0.08 & 0.12 & 0.10 & 0.11 & $<0.03$ \\
\hline Total & 98.9 & 98.6 & 98.6 & 99.5 & 99.7 & 100.5 & 99.8 & 99.2 & 99.4 & 100.2 & 100.2 & 100.3 & 100.1 & 98.8 & 98.4 \\
\hline$M g^{\prime}$ & 85.5 & 68.9 & 63.5 & 57.9 & 53.7 & 49.5 & 68.2 & 66.2 & 63.5 & 57.6 & 57.4 & 48.3 & 46.7 & 45.5 & -0 \\
\hline \multicolumn{16}{|c|}{ Molecular proportions of wollastonite (Wo), enstatite (En), and ferrosilite (Fs) } \\
\hline Wo & 2.1 & 10.2 & 3.6 & 4.9 & 4.5 & 7.1 & 39.9 & 38.8 & 35.5 & 28.7 & 32.0 & 33.9 & 31.5 & 33.2 & 18.8 \\
\hline En & 83.6 & 61.9 & 61.3 & 55.1 & 51.3 & 46.0 & 41.0 & 40.5 & 40.9 & 41.1 & 39.0 & 31.9 & 32.0 & 30.4 & $<0.1$ \\
\hline & 14.3 & 28.0 & 35.1 & 40.0 & 44.2 & 46.9 & 19.1 & 20.7 & 23.5 & 30.2 & 29.0 & 34.2 & 36.5 & 36.4 & 81.1 \\
\hline
\end{tabular}

$M g^{\prime}=$ atomic $\mathrm{Mg} /(\mathrm{Mg}+\mathrm{Fe}) \times 100$.

Px 1 is a coarse orthopyroxene clast $(1 \mathrm{~mm})$. Avg. = mean of four spot analyses.

Px 8 and Px 9 are coarsely exsolved; in both cases, augite is the host.

All other high-Ca pyroxene clasts are finely exsolved; composite analyses were made with a $20 \mu \mathrm{m}$ beam.

the nonmare components of Yamato $82192 / 3$ and Yamato 86032 may, in fact, be the same and occur in similar proportions. Significant differences in the ratio of nonmare to mare material in the regolith occur laterally over distances as small as a kilometer at the Apollos 15 and 17 sites and vertically over much smaller distances (Korotev, 1987b, 1995; Morris et al., 1989; Korotev and Kremser, 1992). Thus the compositional differences (including $\mathrm{Mg}^{\prime}$; Fig. 9) between Yamato $82192 / 3$ and Yamato 86032 are in no way evidence against their ejection from the lunar surface by a single small impact.

\section{Are MAC 88104/5 and QUE 93069 Related?}

Because MAC 88104/5 and QUE 93069 are compositionally more similar to each other than are Yamato 82192/3 and Yamato 86032 , it is reasonable to question whether they might be also have derived from the same lunar source crater. Compositional data alone

TABLE 5. Compositions of olivine clasts in QUE 93069,31.

$\begin{array}{lcccc} & \text { Oliv I } & \text { Oliv 2 } & \text { Oliv 3 } & \text { Oliv } 4 \\ \mathrm{SiO}_{2} & 36.0 & 38.8 & 36.8 & 35.5 \\ \mathrm{TiO}_{2} & 0.05 & 0.03 & 0.04 & 0.02 \\ \mathrm{Al}_{2} \mathrm{O}_{3} & <0.04 & 0.58 & <0.04 & 0.04 \\ \mathrm{Cr}_{2} \mathrm{O}_{3} & <0.04 & 0.40 & <0.04 & <0.04 \\ \mathrm{FeO} & 36.7 & 19.9 & 29.0 & 31.22 \\ \mathrm{MnO} & 0.40 & 0.27 & 0.36 & 0.41 \\ \mathrm{MgO} & 26.8 & 38.8 & 32.8 & 29.71 \\ \mathrm{CaO} & 0.16 & 0.56 & 0.18 & 0.30 \\ \mathrm{Na}_{2} \mathrm{O} & <0.03 & <0.03 & <0.03 & <0.03 \\ \mathrm{Total} & 100.1 & 99.3 & 99.2 & 97.2 \\ \mathrm{Mg} & 56.6 & 77.7 & 66.9 & 62.9\end{array}$

Molecular proportions of fayalite $(\mathrm{Fa})$, forsterite $(\mathrm{Fo})$,

\begin{tabular}{cccrr}
\multicolumn{5}{c}{ and $\mathrm{Ca}_{2} \mathrm{SiO}_{4}(\mathrm{Ca})$} \\
$\mathrm{Fa}$ & 43.3 & 22.2 & 33.0 & 36.9 \\
$\mathrm{Fo}$ & 56.5 & 77.0 & 66.7 & 62.6 \\
$\mathrm{Ca}$ & 0.2 & 0.8 & 0.3 & 0.5 \\
\hline
\end{tabular}

$M g^{\prime}=$ atomic $(\mathrm{Mg} /(\mathrm{Mg}+\mathrm{Fe}) \times 100$. cannot prove or disprove source-crater pairing, but it is informative to consider, independent of any arguments based on exposure age (Nishiizumi et al., 1995; Spettel et al., 1995; Swindle et al., 1995; Thalmann and Eugster, 1995), whether the compositions of MAC $88104 / 5$ and QUE 93069 can be related by any simple additive process, as for Yamato 82192/3 and Yamato 86032.

We have attempted to model the composition of QUE. 93069 as a mixture consisting largely of MAC 88104/5 and minor components rich in siderophile and incompatible trace elements in order to account for the compositional differences discussed above. Siderophile element concentrations in QUE 93069 are matched well by addition of $\sim 1 \% \mathrm{CI}$ chondrites (water free) to MAC $88104 / 5$ (e.g., Fig. 8). To a first approximation, the greater abundances of incompatible trace element of QUE 93069 are equivalent to the addition of $\sim 1 \%$ high-K KREEP or 2-3\% mafic impact-melt breccias ("LKFM" or "MKFM") such as those found at the Apollo sites. In detail, however, we have found no known REE-rich component that when added to MAC 88104/5 accounts well for the relative abundances of the REEs in QUE (Fig. 12). Also, the higher MgO concentrations but similar $\mathrm{Al}_{2} \mathrm{O}_{3}$ and $\mathrm{FeO}$ concentrations of QUE 93069 cannot be explained simply by addition to MAC $88104 / 5$ of a small proportion $(<10 \%)$ of any reasonable component or combinations of components. Addition of components representing the moderately high$\mathrm{Mg}$ ' lithologies found in QUE 93069 (next section) could account for the greater $\mathrm{Mg}$ concentration and $\mathrm{Mg}^{\prime}$ of QUE 93069 but only if accompanied by enough plagioclase to account for the similarity in $\mathrm{Al}_{2} \mathrm{O}_{3}$ concentrations. For example, a magnesian granulitic breccia of noritic anorthosite composition $\left(>29 \% \mathrm{Al}_{2} \mathrm{O}_{3}\right)$ might account for the differences, but at least $20 \%$ of such a component would be required. Thus, we suspect that the two meteorites are not closely related and that the compositional differences between MAC 88104/5 and QUE 93069, although small, arise because the two meteorites contain at least some significantly different lithologies, but the compositional similarities result because most highlands regions (and the components of these two meteorites) are dominated by ITEpoor, ferroan noritic anorthosites. 
TABLE 6. Compositions of glass clasts in QUE 93069,31.

\begin{tabular}{|c|c|c|c|c|c|c|c|c|c|c|c|c|c|c|c|}
\hline & $\begin{array}{l}\text { glass- } \\
\text { clast } 3\end{array}$ & $\begin{array}{l}\text { glass- } \\
\text { clast } 4\end{array}$ & $\begin{array}{l}\text { glass- } \\
\text { clast } 9\end{array}$ & $\begin{array}{l}\text { glass- } \\
\text { clast } 2\end{array}$ & $\begin{array}{l}\text { glass- } \\
\text { clast } 1\end{array}$ & $\begin{array}{l}\text { glass- } \\
\text { clast } 13\end{array}$ & $\begin{array}{l}\text { glass- } \\
\text { clast } 19\end{array}$ & $\begin{array}{l}\text { glass- } \\
\text { clast } 6\end{array}$ & $\begin{array}{l}\text { glass- } \\
\text { clast } 7\end{array}$ & $\begin{array}{l}\text { glass- } \\
\text { clast } 5\end{array}$ & $\begin{array}{l}\text { glass- } \\
\text { clast } 17\end{array}$ & $\begin{array}{l}\text { glass- } \\
\text { clast } 10\end{array}$ & $\begin{array}{l}\text { glass- } \\
\text { clast } 8\end{array}$ & $\begin{array}{l}\text { HASP } \\
\text { clast } 12\end{array}$ & $\begin{array}{c}{ }^{*} \text { Aggl } \\
\text { glass }\end{array}$ \\
\hline $\mathrm{iO}_{2}$ & 44.2 & 45.0 & 43.0 & 43.4 & 43.4 & 45.0 & 45.5 & 45.5 & 45.5 & 47.7 & 47.5 & 48.8 & 40.7 & 39.2 & 44.5 \\
\hline $\mathrm{TiO}_{2}$ & 0.15 & 0.19 & 0.10 & 0.16 & 0.15 & 0.26 & 0.40 & 0.30 & 0.48 & 1.01 & 0.63 & 1.30 & 9.37 & 0.26 & 0.24 \\
\hline $\mathrm{Al}_{2} \mathrm{O}_{3}$ & 31.6 & 30.9 & 30.7 & 29.0 & 28.9 & 27.1 & 23.8 & 22.3 & 20.4 & 20.0 & 17.4 & 11.0 & 9.89 & 33.6 & 27.1 \\
\hline $\mathrm{Cr}_{2} \mathrm{O}_{3}$ & 0.11 & 0.06 & 0.08 & 0.09 & 0.12 & 0.15 & 0.15 & 0.17 & 0.34 & 0.24 & 0.28 & 0.51 & 0.57 & 0.06 & 0.08 \\
\hline $\mathrm{FeO}$ & 2.59 & 3.14 & 3.56 & 4.86 & 4.56 & 5.67 & 6.41 & 6.59 & 12.8 & 8.91 & 14.0 & 15.4 & 17.6 & 2.89 & 4.10 \\
\hline $\mathrm{MnO}$ & 0.07 & 0.06 & 0.06 & 0.04 & 0.11 & 0.10 & 0.11 & 0.08 & 0.21 & 0.06 & 0.23 & 0.18 & 0.27 & 0.02 & 0.08 \\
\hline $\mathrm{MgO}$ & 3.57 & 3.18 & 2.90 & 6.06 & 4.41 & 6.59 & 8.39 & 11.3 & 4.42 & 7.90 & 7.27 & 12.5 & 10.2 & 4.57 & 7.90 \\
\hline $\mathrm{CaO}$ & 18.4 & 17.7 & 18.0 & 16.7 & 17.4 & 15.5 & 14.1 & 13.1 & 13.0 & 13.5 & 13.5 & 9.37 & 10.5 & 19.1 & 15.48 \\
\hline $\mathrm{Na}_{2} \mathrm{O}$ & 0.07 & 0.42 & 0.26 & 0.07 & 0.29 & 0.26 & 0.36 & 0.14 & 0.77 & 0.50 & 0.18 & 0.24 & 0.07 & $<0.03$ & 0.32 \\
\hline $\mathrm{K}_{2} \mathrm{O}$ & $<0.03$ & $<0.03$ & $<0.03$ & $<0.03$ & 0.03 & $<0.03$ & 0.13 & 0.03 & 0.09 & 0.03 & $<0.03$ & $<0.03$ & $<0.03$ & $<0.03$ & 0.04 \\
\hline $\mathrm{P}_{2} \mathrm{O}_{5}$ & n.a. & n.a. & n.a. & n.a. & na. & $<0.03$ & 0.08 & na. & n.a. & n.a. & $<0.03$ & n.a. & n.a. & $<0.03$ & n.a. \\
\hline Sum & 100.8 & 100.6 & 98.7 & 100.4 & 99.5 & 100.6 & 99.4 & 99.5 & 98.0 & 99.9 & 100.9 & 99.3 & 99.1 & 99.6 & 99.8 \\
\hline$M g$ & 1.1 & 64.4 & 59.2 & 69.0 & & 67.5 & 70.0 & 75.3 & 38.1 & 61.2 & 48.1 & 59.1 & 50.8 & 73.8 & 77.5 \\
\hline$A n^{\prime}$ & 99.2 & 95.7 & 97.3 & 99.3 & 96.7 & 97.0 & 94.3 & 97.8 & 88.1 & 92.9 & 96.7 & 93.1 & 97.6 & 99.8 & 96.1 \\
\hline \multicolumn{16}{|c|}{ mineralogy (modified CIPW norm) } \\
\hline lag & 85.9 & 85.5 & 86.0 & 79.1 & 80.6 & 74.4 & 67.1 & 61.8 & 60.2 & 56.7 & 47.8 & 31.2 & 27.5 & 92.1 & 75.5 \\
\hline Opx & 4.38 & 5.57 & 0 & 4.21 & 0.41 & 12.8 & 17.3 & 21.5 & 23.1 & 28.4 & 33.5 & 50.4 & 32.3 & -21.5 & 8.03 \\
\hline Cpx & 4.34 & 4.42 & 5.65 & 3.27 & 7.30 & 3.46 & 5.57 & 3.93 & 10.9 & 12.1 & 16.6 & 14.6 & 21.0 & 2.39 & 3.52 \\
\hline Oliv & 4.96 & 4.09 & 8.16 & 13.0 & 11.2 & 8.5 & 8.93 & 11.9 & 4.40 & 0 & 0.52 & 0 & 0 & 26.5 & 12.4 \\
\hline m & 0.28 & 0.36 & 0.19 & 0.30 & & 0.4 & 0.76 & & 0.9 & 1.92 & 1.19 & 2.49 & 18.0 & 0.50 & 0.46 \\
\hline $\mathrm{Chm}$ & 0.16 & 0.09 & 0.12 & 0.13 & 0.18 & 0.22 & 0.22 & 0.25 & 0.51 & 0.35 & 0.41 & 0.76 & 0.85 & 0.09 & 0.12 \\
\hline $\mathrm{Qtz}$ & 0 & () & 0 & 0 & 0 & 0 & 0 & 0 & 0 & 0.51 & 0 & 0.57 & 0.34 & 0 & 0 \\
\hline
\end{tabular}

n.a. $=$ not analyzed. $M g^{\prime}=$ molar $\mathrm{MgO} /(\mathrm{MgO}+\mathrm{FeO}) \times 100 . A n^{\prime}=$ normative $\mathrm{An} /(\mathrm{An}+\mathrm{Ab}+\mathrm{Or}) \times 100.1 \mathrm{IASP}=$ high alumina, silica poor. Note negative Opx in the norm.

${ }^{*} A g g l$ Gls $=$ agglutinate glass; average of three analyses.

TABLE 7. Compositions of lithic clasts and cocxisting minerals in QUE 93069,31.

\begin{tabular}{|c|c|c|c|c|c|c|c|c|c|c|}
\hline & \multicolumn{3}{|c|}{ I.ithic clast 1} & \multicolumn{2}{|c|}{ Lithic clast 2} & \multirow{2}{*}{$\begin{array}{l}\text { Lithic } \\
\text { Clast } 3\end{array}$} & \multicolumn{2}{|c|}{ Plag-Px clast } & \multicolumn{2}{|c|}{ Plag - Oliv clast } \\
\hline & Plag & $\mathrm{Px}$ & Oliv & Plag & Px & & Plag & $\mathrm{Px}$ & Plag & Oliv \\
\hline $\mathrm{SiO}_{2}$ & 43.4 & 52.0 & 36.6 & 45.2 & 44.9 & 43.4 & 44.3 & 52.3 & 43.5 & 36.5 \\
\hline $\mathrm{TiO}_{2}$ & $<0.02$ & 0.74 & 0.05 & $<0.02$ & 0.84 & 0.03 & $<0.02$ & 0.26 & $<0.02$ & 0.04 \\
\hline $\mathrm{Al}_{2} \mathrm{O}_{3}$ & 35.6 & 1.27 & 0.03 & 35.9 & 9.9 & 34.0 & 35.8 & 0.50 & 35.5 & 0.00 \\
\hline $\mathrm{Cr}_{2} \mathrm{O}_{3}$ & $<0.02$ & 0.45 & 0.05 & $<0.02$ & 0.36 & $<0.02$ & $<0.02$ & 0.15 & $<0.02$ & 0.06 \\
\hline $\mathrm{FeO}$ & 0.18 & 13.8 & 29.8 & 0.31 & 20.4 & 0.53 & 0.21 & 26.0 & 0.25 & 37.6 \\
\hline $\mathrm{MnO}$ & $<0.02$ & 0.29 & 0.35 & $<0.02$ & 0.28 & 0.02 & 0.04 & 0.40 & $<0.02$ & 0.37 \\
\hline $\mathrm{MgO}$ & 0.11 & 19.0 & 31.8 & 0.20 & 13.9 & 0.40 & 0.30 & 18.8 & 0.08 & 25.8 \\
\hline $\mathrm{CaO}$ & 189 & 11.3 & 0.24 & 19.3 & 9.5 & 19.3 & 19.1 & 2.18 & 19.5 & 0.19 \\
\hline $\mathrm{Na}_{2} \mathrm{O}$ & 0.33 & 0.02 & $<0.03$ & 0.39 & $<0.03$ & 0.30 & 0.33 & $<0.03$ & 0.33 & $<0.03$ \\
\hline $\mathrm{K}_{2} \mathrm{O}$ & $<0.03$ & $\mathrm{n} \mathbf{a}$. & na. & $<0.03$ & n.a. & 0.04 & $<0.03$ & $<0.03$ & $<0.03$ & $<0.01$ \\
\hline Sum & 99.8 & 98.9 & 98.9 & 101.3 & 100.1 & 98.0 & 100.1 & 100.5 & 99.2 & 100.5 \\
\hline$M g^{\prime}$ & & 71.0 & 65.5 & & 54.9 & 57.1 & & 56.3 & & 55.0 \\
\hline$A n^{\prime}$ & 96.9 & & & 96.5 & & 97.1 & 96.9 & & 97.0 & \\
\hline
\end{tabular}

$M g^{\circ}=$ molar $\mathrm{MgO} /(\mathrm{MgO}+\mathrm{FeO}) \times 100 ; A n^{\prime}=\mathrm{An} /(\mathrm{An}+\mathrm{Ab}+\mathrm{Or}) \times 100$ of plagioclase. $\mathrm{n} . \mathrm{a} .=$ not analyzed.

Lithic clast $\mathrm{I}$ is $-300 \mu \mathrm{m}$ across and fine grained (Fig. 3b). L ithic clast 2 is $-200 \mu \mathrm{m}$ across, with very line grained, intergranular texture (Fig. 3c); cf. A15 pigeonitc basalt or aluminous low-Ti basalt. Lithic clast 3 is $200 \mu \mathrm{m}$ across, with very fine grained. granoblastic texture. Composition is an average of two broad-beam analyses. $A n^{\prime}$ value of lithic clast 3 is normative $A n /(A n+\Lambda b+O r)$. The other two clasts consist of clusters of adjoining plagioclase and mafic silicates.

\section{Lithologic Components of QUE 93069}

Lunar meteorite QUI: 93069 is a thoroughly polymict rock. From the nature of the clasts and the bulk composition of the meteorite, we can infer what the components or precursors were in the regolith from which it derives and something about their compositions. In thin section, QUE 93069 contains some mare components but they are not abundant; we found only two glass clasts and one possible lithic clast of mare composition in QUE 93069,31. Assuming that the average nonmare component has at least $0.2 \% \mathrm{TiO}_{2}$ (a value less than nearly all feldspathic granulitic breccias from $A$ pollo
16, e.g., Stöffler et al., 1985; Lindstrom and Lindstrom. 1986) and, conservatively, that the average mare component of QUI: 93069 has at least $2 \% \mathrm{TiO}_{2}$, then the low $\mathrm{TiO}_{2}$ of QUE $93069(0.24 \%)$ restricts the abundance of mare material to $<2 \%$. Thus, it is unlikely that any substantial portion of the $\mathrm{Fe}$ and $\mathrm{Mg}$ in QUE 93069 is contributed by mare-derived components and we conclude that, unlike Yamato $82192 / 3$, the low $\mathrm{Mg}^{\prime}$ of QUE 93069 is intrinsic to the nonmare components. Components rich in incompatible elements are not present among the clasts we analyzed (e.g., no glasses with as much as $0.25 w_{1} \% \mathrm{~K}_{2} \mathrm{O}$ or $\mathrm{P}_{2} \mathrm{O}_{5}$ ). Thus, we find no evidence of a KREEP- 
TABLE 8. Mean INAA results for subsplits of Yamato 86032.

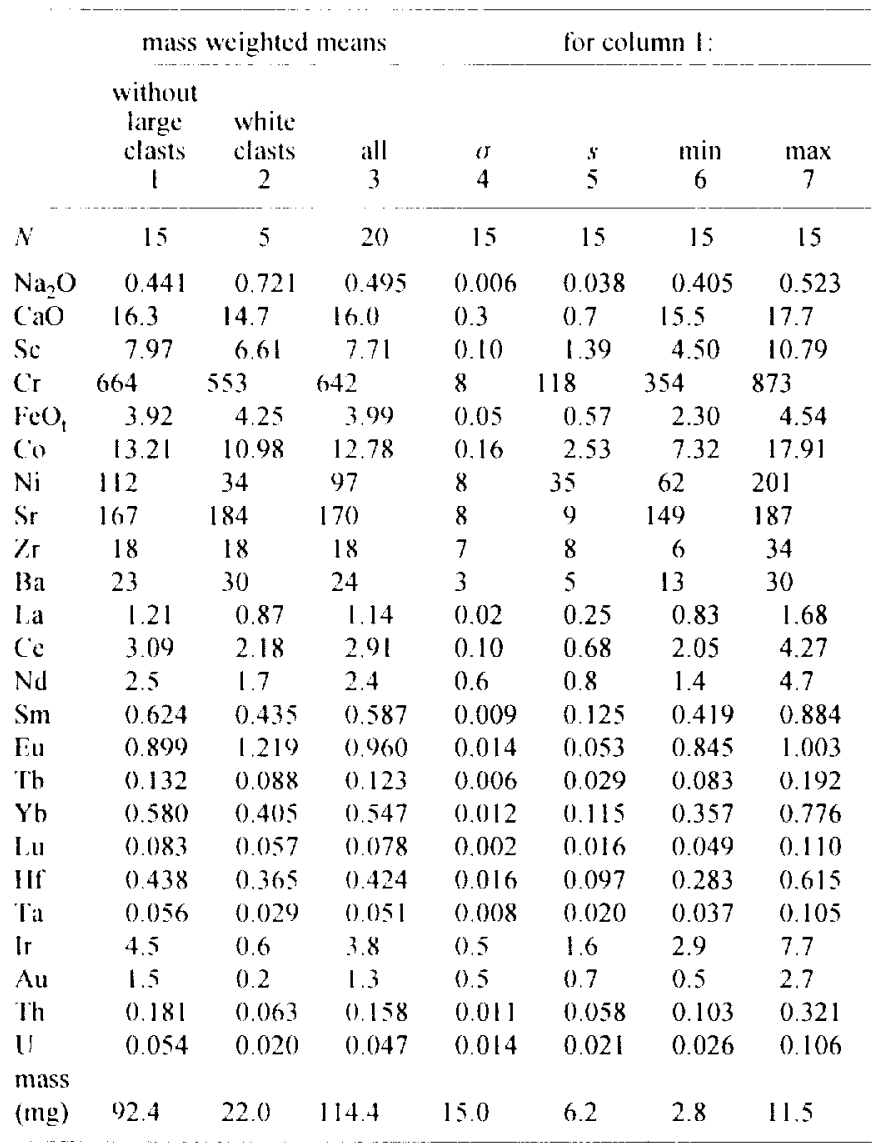

Concentration units in $\mu \mathrm{g} / \mathrm{g}$, except oxides in $\mathrm{cg} / \mathrm{g}$ (mass percent) and $\mathrm{Ir}$ and Au in $\mathrm{ng} / \mathrm{g} ; \mathrm{FeO}_{\mathrm{t}}=$ total $\mathrm{Fe}$ as $\mathrm{FeO} . N=$ number of subsplits averaged; $\sigma=$ estimated analytical uncertainty (standard deviation) for a single subsplit; $s$ $=$ sample standard deviation of all subsplits of column $1(N=15)$. The 15 subsplits of column 1 contained no large clasts; the 5 subsplits of column 2 were each dominated by whitish, Na-rich clasts. Column 3 represents the best "whole-rock" composition.

like component and assume that concentrations of $\mathrm{Fe}$ and $\mathrm{Mg}$ contributed by any possible KREEP components or Apollo-like mafic impact-melt breceias is negligible

Most of the components of QUE 93069 appear to derive from the ferroan-anorthositic suite of nommare plutonic rocks, although anorthositic clasts deriving from magnesian-suite precursors also occur. These include the large, moderately magnesian, partially devitrified clast (Table 1). the magnesian agglutinitic glass (Table 6 ), and the very magnesian $\left(E n_{84}\right)$ orthopyroxene clast (Table 4 ) This clast has a composition similar to pyroxene found, for example, in norite 78235 (Sclar and Bauer, 1975) and troctolite 76535 (Dymek et al. 1975). Assuming that (1) QUJE 93069 is essentially a binary mixture of nommare components derived from magnesian- and ferroan anorthositic-suite lithologies, (2) the average composition of the magnesian components is generally similar to (or even somewhat more magnesian than) the large partially devitrified clast, and (3) the $\mathrm{Mg} / \mathrm{Fe}$ ratio of the nonmare ferroan components is the same as for $\mathrm{MAC} 88104 / 5\left(\mathrm{Mg}^{\prime}=62\right)$. then the meteorite consists of $-20 \%$ magnesian material and $80 \%$ material with an average composition of ferroan noritic anorthosite $\left(-30 \% \mathrm{Al}_{2} \mathrm{O}_{3}\right.$, i.e., $87 \%$ plagioclase by volume). This ferroan component is similar to that inferred to be the precursor to ferroan igneous rocks from North Ray
TABIE 9. Major-element compositions of subsamples of Y86032,115

\begin{tabular}{|c|c|c|c|c|c|c|}
\hline & \multicolumn{2}{|c|}{ fused beads* } & \multicolumn{2}{|c|}{ glass vein ${ }^{\dagger}$} & \multicolumn{2}{|c|}{ glassy matrix ${ }^{\dagger}$} \\
\hline & mean & $s$ & mean & $s$ & mean & $s$ \\
\hline $\mathrm{SiO}_{2}$ & 44.0 & 0.5 & 45.0 & 0.3 & 44.6 & 0.3 \\
\hline $\mathrm{TiO}_{2}$ & 0.17 & 0.04 & 0.24 & 0.01 & 0.23 & 0.03 \\
\hline $\mathrm{Al}_{2} \mathrm{O}_{3}$ & 30.6 & 0.6 & 28.3 & 0.3 & 28.0 & 0.7 \\
\hline $\mathrm{Cr}_{2} \mathrm{O}_{3}$ & 0.09 & 0.01 & 0.12 & 0.05 & 0.09 & 0.01 \\
\hline $\mathrm{FeO}$ & 3.78 & 0.26 & 4.95 & 0.10 & 4.99 & 0.33 \\
\hline $\mathrm{MnO}$ & 0.053 & 0.006 & 0.074 & 0.011 & 0.084 & 0.022 \\
\hline $\mathrm{MgO}$ & 4.62 & 0.40 & 4.75 & 0.12 & 5.68 & 0.39 \\
\hline $\mathrm{CaO}$ & 16.2 & 0.4 & 16.3 & 0.1 & 16.0 & 0.2 \\
\hline $\mathrm{Na}_{2} \mathrm{O}$ & 0.38 & 0.03 & 0.47 & 0.02 & 0.38 & 0.00 \\
\hline $\mathrm{K}_{2} \mathrm{O}$ & 0.019 & 0.003 & 0.021 & 0.009 & 0.021 & 0.004 \\
\hline $\mathrm{P}_{2} \mathrm{O}_{5}$ & 0.016 & 0.005 & 0.020 & 0.007 & 0.021 & 0.016 \\
\hline Total & 99.9 & & 100.2 & & 100.1 & \\
\hline$N$ & 7 & & 5 & & 4 & \\
\hline$M g^{\prime}$ & 68.5 & & 63.1 & & 67.0 & \\
\hline$A n^{\prime}$ & 96.1 & & 94.8 & & 95.7 & \\
\hline
\end{tabular}

* Average for fused beads prepared from seven of the matrix-rich subsamples analyzed by INAA. $N=$ number of beads averaged; $s=$ sample standard deviation of the bead-to-bead variation

${ }^{\dagger}$ Compositions of the glass vein and glassy matrix of the dark-matrix breccia taken on thin section $86032,115 \mathrm{~A} . N=$ number of spots averaged; $s=$ sample standard deviation of the spot-to-spot variation.

$M g^{\prime}=$ molar $\mathrm{MgO} /(\mathrm{MgO}+\mathrm{FeO}) ; A n^{\prime}=$ normative $A \mathrm{n} /(A \mathrm{n}+\mathrm{Ab}+\mathrm{Or})$.

TABLE 10. Example of adding a hypothetical low-Ii mare basalt ( \pm minor components) to Yamato 86032 to approximate the composition of Yamato $82192 / 3$

\begin{tabular}{|c|c|c|c|c|c|c|c|}
\hline & \multirow{2}{*}{$\begin{array}{c}\text { Yamato } \\
86032\end{array}$} & \multirow[b]{2}{*}{ CI } & \multirow[b]{2}{*}{ KRELP } & \multirow{2}{*}{$\begin{array}{c}\text { mare } \\
\text { basalt }\end{array}$} & \multicolumn{3}{|c|}{ Yamato $82192 / 3$} \\
\hline & & & & & est & obs & unc \\
\hline$f(\%)$ & 93.1 & 0.06 & -0.18 & 7.0 & 100.0 & $-\cdots$ & - \\
\hline $\mathrm{TiO}_{2}$ & 0.18 & 0.10 & 2.00 & 1.5 & 0.27 & 0.27 & 0.11 \\
\hline $\mathrm{Al}_{2} \mathrm{O}_{3}$ & 28.4 & 2.2 & 15.1 & 10.5 & 27.2 & 26.9 & 1.1 \\
\hline $\mathrm{FeO})_{t}$ & 4.28 & 33.3 & 10.3 & 19. & 5.32 & 5.29 & 0.79 \\
\hline $\mathrm{MgO}$ & 5.26 & 22.3 & 8.29 & 10.7 & 5.65 & 5.64 & 0.74 \\
\hline $\mathrm{CaO}$ & 16.4 & 1.77 & 9.8 & 10 & 15.9 & 15.5 & 0.8 \\
\hline $\mathrm{Na}_{2} \mathrm{O}$ & 0.435 & 0.92 & 0.94 & 0.25 & 0.42 & 0.40 & 0.04 \\
\hline $\mathrm{Sc}$ & 8.3 & 7.9 & 23 & 48 & 11.1 & 11.1 & 2.6 \\
\hline $\mathrm{Cr}$ & 680 & 3620 & 1200 & 3670 & 890 & 890 & 16.5 \\
\hline Co & 14.5 & 683 & 25 & 45 & 17.0 & 16.9 & 2.1 \\
\hline $\mathrm{Ni}$ & 134 & 14960 & 100 & 30 & 136 & 136 & 14 \\
\hline $\mathrm{Ba}$ & 26 & 3.2 & 1300 & 50 & 25 & 25 & 3 \\
\hline la & 1.26 & 0.32 & 110 & 4. & 1.26 & 1.31 & 0.15 \\
\hline $\mathrm{Sm}$ & 0.616 & 0.20 & 48 & 2.7 & 0.68 & 0.62 & 0.05 \\
\hline$\Gamma u$ & 0.93 & 0.076 & 3.3 & 0.7 & 0.91 & 0.87 & 0.07 \\
\hline $\mathrm{Yb}$ & 0.60 & 0.22 & 36 & 2.4 & 0.66 & 0.67 & 0.10 \\
\hline L,u & 0.086 & 0.033 & 5 & 0.37 & 0.097 & 0.101 & 0.016 \\
\hline Th & 0.21 & 0.04 & 22 & 0.45 & 0.19 & 0.19 & 0.04 \\
\hline$M g^{\prime}$ & 68.7 & 54 & 59 & 50 & 65.4 & 6.5 .5 & 4.8 \\
\hline
\end{tabular}

Concentration units in $\mu \mathrm{g} / \mathrm{g}$, except oxides in co/g (mass percent) and $\mathrm{Mg}$. in mole percent; $\mathrm{FeO}_{1}=$ total $\mathrm{Fe}$ as $\mathrm{FeO}$ and $\mathrm{Mg}^{\prime}=$ bulk $\mathrm{Mg} /(\mathrm{Mg}+\mathrm{Fc})$. Component compositions: Yamato $86032=$ mean calculated from data in Kocberl et al (1989, 1990), Warren and Kallemcyn (1991), Lindstrom et al. (1991), and this work; $\mathrm{CI}$ (carbonaceous chondrites, $\mathrm{H}_{2} \mathrm{O}$ free) from Korotev and Kremser (1992); KREEP from Warren (1989). The mare basalt component does not represent any known type of basalt; the concentrations were calculated to provide a reasonable fit but to be consistent still with known samples of low-Ti basalt. Yamato 82192/3 "est" (estimated) is obtained by combining the components in the indicated proportions $(f)$; "obs" (observed) = mean of data from Fukuoka et al. (1986), Bischoff et al. (1987). Koeberl (1988), Lindstrom et al (1991), Warren and Kallemeyn (1991), with $-95 \%$ confidence limits on mean concentrations ("unc") 


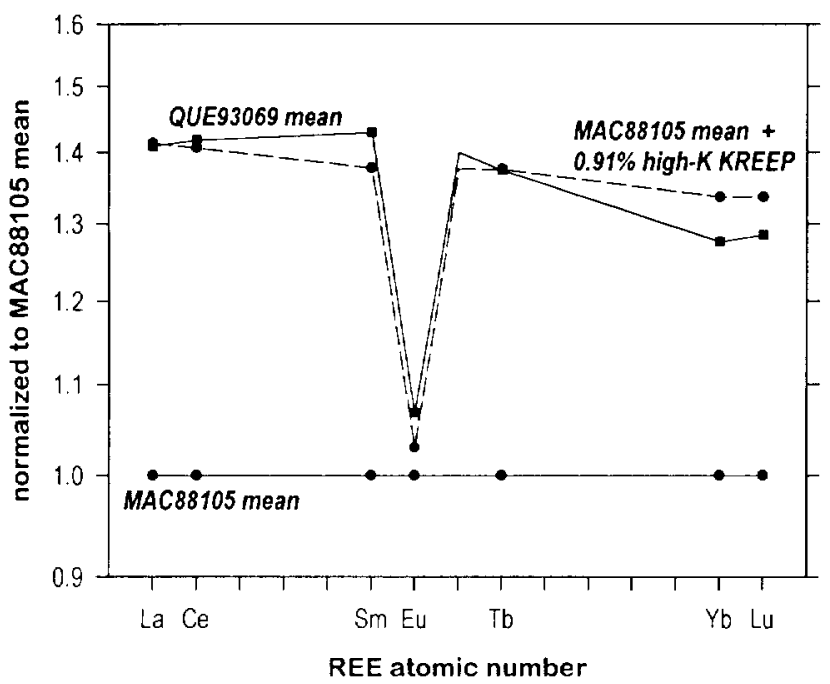

FIG. 12. Comparison of rare earth concentrations in QUE 93069 and MAC 88105. The mean La/Yb ratio of QUE 93069 is $2.75 \pm 0.09( \pm 95 \%$ contidence, based on 11 analyses of Table 2 ). which is significantly greater than that of MAC 88104/5, 2.49 \pm 0.05 (based on 17 analyses of Jolliff $e t$ al, 1991). Addition of high-K KREEP (Warren, 1989) to MAC 88104/5 does not account for the relative REE abundances observed in QUE: 93069 thus, the "high" concentrations of incompatible trace clements in QUF 93069 compared to MAC $88104 / 5$ and other feldspathic lunar meteorites (Fig. 7b) is probably not simply the result of a KREEP component but is a feature of the igneous precursors of the meteorite

crater, Apollo 16, by Jolliff and Ilaskin (1995). Such a component, although more mafic than anorthosite sensu stricto, should be common among the upper-crustal crystallization products of a lunar magma ocean.

\section{The Fe Abundance of the Lunar Highlands}

Based on spectral reflectance data obtained by the Clementine mission, which provided the first global coverage of the lunar surface, Lucey et al. (1995) concluded that the most typical (mode) concentration of $\mathrm{FeO}$ in the regolith at the surface of the lunar highlands is $-3.6 \%(2.8 \%$ as $\mathrm{Fe})$; in their analysis, approximately two-thirds of the highlands surface has between $2.3 \%$ and $4.9 \% \mathrm{FeO}$ (Fig. 6). At first appearance, the Clementine results are surprising in that at least three other lines of evidence suggest that the Fe abundance of the lunar highlands surface is $>3.6 \%$. We argue here that data for Apollo 16 regolith samples and the Apollo orbiting $x$-ray and gamma-ray experiments are not inconsistent with the Clementine results, but that the strongest data, that for the lunar meteorites, are not easily reconciled with the low $\mathrm{Fe}$ abundance obtained from the analysis of the Clementine data

Apollo 16-The Apollo 16 mission sampled a site of feldspathic highlands more distant from the major basins than any other mission, and the soil obtained there is the most feldspathic collected on the Moon. Thus, the Apollo 16 site and its materials are the standards of comparison for other highlands regions and samples. As noted by Lucey et al. (1995), soil from the Apollo 16 mission contains considerably greater than $3.6 \% \mathrm{FeO}$. Soil from the Descartes Formation, as represented by the soils of North Ray crater, averages $-4.1 \%$ FeO (range: $3.0-5.0$; Korotev, 1996b). Mature soil from the Cayley plains (central and southern sampling stations) averages 5.5\% FeO (range: $4.8-5.9 \%$; Korotev, 1981, and updated database). (The value of $4.9 \% \mathrm{FeO}, 3.6 \% \mathrm{Fe}$, for Apollo 16 soil cited by lucey et al. 1995, appears to be an average of Cayley plains and Descartes soils.) However, the Apollo 16 region is not typical of vast areas of the highlands because in the regoliths of both the Descartes Formation and the Cayley plains Fe concentrations are anomalously high as a result of the site's proximity to major basins. For example, mature soil from the Cayley plains consists of $\sim 30 \%$ mafic impactmelt breccias (Korotev, 1996a; Kempa et al., 1980; Morris et al., 1986; Borchardt et al. 1986). These breccias were presumably formed by, or are otherwise related to, basin-forming impacts. Another $-6 \%$ is mare glass and basalt (Kempa et al. 1980; Korotev, 1996a). Thus, 45\% of the Fe in Apollo 16 soil is contained in the components of mafic impact-melt breccia and another $20 \%$ in the components of mare-derived material (Korotev, 1996a). If these synand post-basin contributions are removed, the $\mathrm{FeO}$ concentration of the residue prebasin components of the $A$ pollo 16 regolith (Cayley plains) is only $-3.0 \%$ (updated from Korotev, 1996a). Similar results are obtained from ancient regolith breccias (Cayley plains) and feldspathic fragmental breccia (Descartes Formation). which are regolith or megaregolith samples that contain mafic impact-melt breccias but are uncontaminated by mare-derived material (Korotev, 1996a,b). Thus, the Apollo 16 data suggest that in a region of highlands uncontaminated by mafic melt cjecta from basins and mare basalt, the $\mathrm{FeO}$ concentration might be as low as $-3 \%$, i.e, lower than the value obtained by Lucey et al., 1995, from the Clementine spectral reflectance data.

Apollo Orbiting X-Ray and Gamma-Ray Experiments-Previous estimates of the average or typical concentration of FeO in the highlands range from $5.1 \%$ (Korotev et al., 1980) to 6.6\% (Taylor, $1975,1982)$. These estimates are based on the partial $(<20 \%) \mathrm{cov}-$ erage of the lunar surface provided by the Apollo orbiting $x$-ray experiments (indirectly, from the anticorrelation of $\mathrm{Fe}$ and $\mathrm{Al}$; Taylor, 1975, 1982) and by the Apollo orbiting gamma-ray experiments (Korotev et al., 1980). However, much of the area analyzed from orbit by the Apollo experiments is in the mixing zone between mare and highlands (Fischer and Pieters, 1995) or is surfaced by ejecta from the nearside basins that includes mafic material excavated from the lower crust or upper mantle. In contrast, most of the low-Fe regions observed by Clementine were on the lunar farside, off the groundtrack of the Apollo missions and distant from basins. Thus, it is likely that estimates for the average concentration of Fe at the surface of the highlands based on data obtained remotely from the Apollo experiments are systematically high, particularly those based on the orbiting x-ray experiment that provided data for nearside regions only.

Lunar Meteorites-Data for the lunar meteorites are not so easily rationalized. The lunar meteorites are generally thought to be samples from several random locations on the lunar surface (e.g., Palme et al., 1991; Warren, 1994). Concentrations of FeO in the feldspathic lunar meteorites range from $4.3 \%$ to $6.1 \%$ (Fig. 6), that is, all are greater than the most typical value of $3.6 \%$ estimated by Lucey et al. (1995) from the Clementine data. If we treat the highlands portion of the distribution of Fig. 7 of Lucey et al. (1995) as a normal distribution with a mean of $3.6 \%$ FeO and a standard deviation of $1.3 \% \mathrm{FeO}$ (a fair approximation), the probability that the five random samples of the population would have $\mathrm{Fe}(\mathrm{O}$ concentrations distributed like those observed in the five feldspathic lunar meteorites (ALHA81005, Yamato 791197, Yamato 82192/3/86032, MAC 88104/5, and QUE 93069; Fig. 6) is only $~ 2 \%$, based on the chi-square test. (For this calculation we use the mass-weighted mean FeO concentrations for Yamato 82192/3/86032 to represent the two points for this meteorite on Fig. 6.) Even the simple probability that all five meteorites would have values greater than the mean 
value for the highlands is similarly low (i.e., $2^{-5}=3 \%$ ). Clearly, there is a significant difference between the average abundance of $\mathrm{FeO}$ in the lunar highlands that we would estimate from the feldspathic lunar meteorites and that estimated by Lucey et al. (1995) from the Clementine data.

\section{Contamination of the Highlands with Mare-Derived Material}

We note, however, that the high FeO concentrations of Yamato 791197 and Yamato $82192 / 3$ are due in large part to their mare components (i.e. crystalline basalt, volcanic glass, and breccias derived therefrom). If the $7 \%$ component of mare basalt estimated for Yamato 82192/3 (Table 10 ) is removed, the residual nonmare component has $-4.3 \% \mathrm{Fe}$. which is about the same as Yamato 86032 and well within the peak of the distribution of Lucey et al, 1995 (Fig. 6). This is a model-dependent result in that the value of $7 \%$ estimated earlicr is based on the assumption that the nonmare portion of Yamato $82192 / 3$ has a composition similar to Yamato 86032 . Ilowever, a total of $7 \%$ mare basalt is consistent with the petrographic data for Yamato 82192/3. Among all clasts $>0.1 \mathrm{~mm}$ in size studied by Bischoff et al. (1987), 11\% (by area) were low-Ti mare basalts ( 5 clasts). In a similar study by Goodrich and Keil (1987), two low-Ti basalt clasts (clasts 1 and 7) represent $6.5 \%$ (by area) of the $>0.1 \mathrm{~mm}$ clasts. Thus, a substantial portion of the Fe in Yamato $82192 / 3$ is carried by mare-derived material.

The abundance of mare material in Yamato 791197 is less easily established. In their study of clasts in a large thin section of Yamato 791197. Ostertag et al. (1986) did not report any clasts of mare basalt, but it is possible that some of the Fe-rich regolith breccias they observed are carricrs of mare-derived material. They also noted that $-32 \%$ of their thin section consisted of clasts $>0.1 \mathrm{~mm}$ in diameter, similar to QUN: 93069 (Fig. 1). Lindstrom et al. (1986) report two clasts of very low-li (VL'T) basalt in three small thin sections. From the backscattered-electron image (including one provided to us by $\mathrm{D}$. Lindstrom of subsample 89,3 , which contained the largest VLT basalt clast), we estimate that the two clasts represent $2.6 \%$ of the total thin-section area or $8.1 \%$ of the area of the $>0.1 \mathrm{~mm}$ clasts (using the value of $32 \%$ clasts from Ostertag, ef al, 1986). Of the eleven $>0.1 \mathrm{~mm}$ clasts in the thin section studied by Goodrich and Keil (1987), 16\% of the area (5 clasts) are VLT mare basalt (1 clast) or "ferroan mafic lithologies that are either low-Ti mare basalts or polymict breccias with a large component of low-Ti mare basalt" (4 clasts). Thus, assuming that the distribution of lithologies is the same for $<0.1 \mathrm{~mm}$ and $>0.1 \mathrm{~mm}$ material, estimates for the abundance of mare basalt in Yamato 791197 are $0 \%, 8 \%$, and $\leq 16 \%$. In Figs. 6 and 9, we show the effect of removing low-Ti mare basalts from Yamato 791197. Removal of $\sim 11 \%$ results in an Fe concentration in the range of the most Fe-poor lunar meteorites, and $11 \%$ is within the range allowable by the petrographic data.

Most feldspathic lunar meteorites contain at least a few percent mare-derived material. Clasts of crystalline mare basalt, breccias with mare basalt components, or glasses of mare composition have been found in ALHA81005 and MAC 88104/5 (Treiman and Drake, 1983; Korotev et al, 1983: Delano, 1991; Neal et al., 1991), although it is unlikely that the total abundance of mare-derived material is more than a few percent in either of these two meteorites. Thus, among the three feldspathic lunar meteorites with $>4.5 \% \mathrm{FeO}$, Al.HA81005 is the only one for which the high Fe abundance cannot easily be attributed to mare basalt.

We interpret the data for Apollo 16 and the feldspathic lunar metcorites in the following way. For areas of the lunar surface that are far enough away from mare basins (and from possible plutons of mare-basalt-like gabbro, i.e, cryptomaria) to have a negligible component of mare basalt, the value of $3.6 \% \mathrm{Fe}$ ) estimated by Lucey et al. (1995) from Clementine data is a reasonable average, one which is consistent with the pre-mare crust as inferred from the samples. However, the lunar meteorites suggest that surface areas totally uncontaminated with mare-derived matcrial are rare 10 absent. Thus, if the metcorites are geographically and geolegically random samples from the Moon, then (1) the $\mathrm{FeO}$ concentrations obtained for the highlands from the Clementine data are improbably low and (2) the interpretation of remotely obtained data on mineralogy and composition of the highlands is forever complicated by the omnipresence of mare-derived material. Alternatively, if the analysis of Lucey et al. (1995) is essentially correct, then we must conclude that our small set of lunar meteorites is somehow a geographically or geologically biased sample of the lunar surface.

\section{SUMMARY AND CONCLUSIONS}

Queen Alexandra Range 93069 is a feldspathic regolith breccia from the lunar highlands with a glassy matrix and abundant clasts. It resembles other feldspathic lunar meteorites in having formed from fragmental debris near the surface of the Moon and having a highly aluminous $\left(29 \% \mathrm{Al}_{2} \mathrm{O}_{3}\right.$, i.e., noritic anorthositc) composition that is poor in incompatible elements compared to feldspathic regolith samples collected on the Apollo missions. It contains at most only a small component of mare-derived material. These characteristics suggest that it derives from an area of the lunar highlands distinct and probably distant from those sampled by Apollo. Compositionally, QUE 93069 most closely resembles MAC 88104/5 as both metcorites are dominated by ferroan, noritic-anorthosite components, although we have found no simple compositional mixing relationship between the two meteorites. Lunar meteorite QUE 93069 contains some magnesian lithologies and, consequently, has a greater concentration of $\mathrm{Mg}$ than does $\mathrm{MAC} 88104 / 5$. It differs from other feldspathic lunar meteorites in being the most aluminous. It also differs in having greater concentrations of incompatible trace elements, although these are still only about a quarter as great as for mature Apollo 16 soil. The slight enrichment in incompatible elements compared to other feldspathic lunar meteorites is probably not related to a KREEP component but reflects differences in the igneous precursors of the regolith of which it is composed. Lunar meteorite QUE 93069 has greater concentrations of siderophile elcments (equivalent to $2.2 \% \mathrm{H}_{2} \mathrm{O}$-free $\mathrm{Cl}$ chondrites) than any other lunar meteorite, which is consistent with its derivation from regolith having a higher degree of exposure at the lunar surface than any other lunar meteorite (Lindstrom et al, 1995; Spettel et al., 1995).

Although cosmic-ray exposure ages indicate that Yamato 82192/3 and Yamato 86032 are probably paired, they differ significantly in average composition compared to the range observed in feldspathic lunar meteorites in that Yamato $82192 / 3$ is compositionally morc mafic and has a lower $\mathrm{Mg} / \mathrm{Fe}$ ratio. However, the average composition of Yamato 82192/3 can be approximated reasonably well by mixing 93\% Yamato 86032 and $7 \%$ material with a low-Ti mare basalt composition. Thus, Yamato $82192 / 3$ and Yamato 86032 could easily have been ejected from the Moon by a single small impact (e.g., Warren, 1994), perhaps into regolith with a layer of ejecta containing mare material. It is likely that the enrichment of $\mathrm{Fe}, \mathrm{Sc}$, and $\mathrm{Cr}$ and low Mg/le ratio in Yamato 791197 compared to the other feldspathic lunar meteorites also results from a low-Ti mare basalt component at the $\sim 10 \%$ level. Thus, the highland components 
of Yamato 791197 and Yamato $82192 / 3$ have $\mathrm{Mg} / \mathrm{Fe}$ ratios greater than that of the bulk meteorites, more similar to Yamato 86032 and ALHA81005, which probably have only a minor amount of marederived components. This leaves only MAC 88104/5 and QUE 93069 as representing low- $\mathrm{Mg} / \mathrm{Fe}$ highlands regions ( $\mathrm{Mg}^{\prime}:$ 62-65).

Concentrations of Fe estimated for the lunar highlands surface by Lucey et al. (1995) from spectral reflectance data obtained by the Clementine mission (mean: $\sim 3.6 \% \mathrm{FeO}$ ) are significantly less than those of the five feldspathic lunar meteorites $(4.3-6.1 \%)$. This discrepancy suggests that either the analysis of the Clementine data underestimated $\mathrm{Fe}$ concentrations at low concentration or our small collection of lunar meteorites is not the random sampling of the lunar surface that is generally assumed. A proper consideration of the Apollo 16 data shows that $\mathrm{FeO}$ concentrations might be as low as $3 \%$ in regions of highlands uncontaminated by mare-derived material and mafic ejecta excavated from below the feldspathic upper crust by basin-forming impacts. However, the lunar meteorites suggest that surface regions effectively devoid of mare-derived material are uncommon.

Acknowledgments-This work was supported by the National Aeronautics and Space Administration through grant NAGW-3343 to L. A. Haskin. Irradiation costs were supported in part by U.S. Department of Energy grant DE-FG07-80ER10725. We thank Dave Lindstrom for providing a backscattered-electron image of Yamato-791197. The paper was improved by thoughtful reviews of A. Bischoff, G. J. Taylor, and P. H. Warren, for which we are grateful.

Editorial handling: P. II. Warren

\section{REFERENCES}

ANDERS F. AND GREVESSF $N$. (1989) Abundances of the elements: Metcoritic and solar. Geochim Cosmochim Acta 53, 197-214

Bersch M. G., TAYI.OR G. J., KIIIL K. and NORMan M. (1991) Mineral compositions in pristine lunar highland rocks and the diversity of highland magmatism. Geophys. Res. Lett. 18, 2085-2088.

Bischorf A (1996) Lunar meteorite Queen Alexandra Range 93069: A lunar highland regolith breccia with very low abundances of mafic components. Meteorit. Planet. Sci. 31, 849-855.

Bischoff A., Palme H., Weber H. W., Stöfler D., Braun O., Spettel B., Begemann F., Wankt: II. AND Ostertag R. (1987) Petrography, shock history, chemical composition and noble gas content of the lunar meteorites Yamato-82192 and -82193. Mem. Natl. Inst Polar Res. Spec. Issue 46, 21-42.

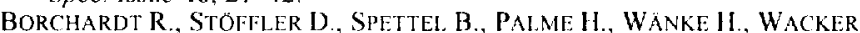
K. AND JFSSBERGER E. K. (1986) Composition, structure, and age of the Apollo 16 subregolith bascment as deduced from the chemistry of postImbrium melt bombs. Proc: Lunar Planet. Sci. Conf. 17th, E43-F:54

DELANO J. W. (1991) Geochemical comparison of impact glasses from lunar meteorites AL11A81005 and MAC88105 and Apollo 16 regolith 64001. Geochim. Cosmochim Acta 55, 3019-3029

DICKINSON T. TAYLOR ( $\mathrm{i}$ J. KEIL K SCHMITT R A. HUGHES S S AND SMITH M. R. (1985) Apollo 14 aluminous mare basalts and their possible relationship in KRELP. Proc. Lunar Planet. Sci. Conf. 15th, C365-C374.

DYMEK R. F., ALBEE A. I. AND ChODOS A. A. (1975) Comparative petrology of lunar cumulate rocks of possible primary origin: Dunite 72415, troctolite 76535 , norite 78235 , and anorthosite 62237. Proc. Lunar Planet. Sci. (Onf 6th, 301-341.

EugSTER O. (1988) Exposure age and terrestrial age of the paired lunar meteorites Yamato-82192 and -82193 from the Moon. Proc. NIPR Symp. Antarct Meteor. 1st, 135-141.

fugster O. Niedermany S. Burger M. Krahenbuhl U, Weber H., CLAYTON R. N. ANI MAYIDA T. K. (1989) Preliminary report on the Yamato-86032 lunar meteorite: III. Ages, noble gas isotopes, oxygen isotopes and chemical abundances. Proc. NIPR Symp. Antarct. Meteor. 2nd, $25-35$.

Fischer E. M. AND PIETERs C. M. (1995) Lunar surface aluminum and iron concentration from (ialileo solid state imaging data, and mixing of mare and highland materials. J. Geophys. Res. 100, 23.279-23.290.

FukUOKA T. (1990) Chemistry of Yamato-793274 lunar meteorite (abstract). NIPR Symp. Antarct. Meteor. 15, 122-123.
Fukuoka T., Laul J, C., Smith M.R., Hughes S. S. and Schmitt R. A (1986) Chemistry of Yamato-82192 and -82193 Antarctic meteorites (abstract). NIPR Symp. Antarct. Meteor. 1 1, 40-42.

GOODRICH C.A. AND KEIL K. (1987) Mare basalts and other clasts in Yamato lunar meteorites Y-791197, -82192 and -82193. Mem. Natl. Inst. Polar Res., Spec. Issue 46, 56-70.

GoOley R. C., Brett R. AND WARner J. L. (1973) Crystallization history of metal particles in Apollo 16 rake samples. Proc. Lunar Planet. Sci. Conf. 4th, 799-810.

Hill D. H., Boynton W. V. and haAg R. A. (1991) A lunar meteorite found outside the Antarctic. Nature 352, 614-617.

JOLLIFF B. L. AND HASKIN L. A. (1995) Cogenetic rock fragments from a lunar soil: Evidence of a ferroan noritic-anorthosite pluton on the Moon. Geochim. Cosmochim. Acta 59, 2345-2374.

JOLLIFF B L. KOROTEV R L. AND HASKIN L. A (1991) A ferroan region of the lunar highlands as recorded in meteorites MAC88104 and MAC88105. Geochim Cosmochim. Acta 55, 3051-3071

JOLLIFF B. L., KOROTEV R. L. AND HASKIN L. A (1993) Lunar basaltic meteorites Yamato-793169 and Asuka-881757: Samples of the same low-Ti mare-lava? Proc. NIPR Symp. Antarct. Meteor. 18th, 214-217.

JOLLIFF B. L.. ROCKOW K. M. AND KOROTEV R. L. (1996) QUE94281: Shallow plutonic VLT components and highlands components (abstract). Lunar Planet. Sci. 27, 615-616.

KaLLEMEYN G. W. AND WARREN P. H. (1983) Compositional implications regarding the lunar origin of the ALHA81005 meteorite. Geophys. Res. Lett. 10, 833-836.

KEMPA M. J., PAPIKE J. J. AND WHITE C. (1980) The Apollo 16 regolith: A petrographically-constrained chemical mixing model. Proc. Lunar Planet. Sci. Conf. 11th, 1341-1355.

KOFBeri C. (1988) Trace element geochemistry of lunar meteorites Yamato-791197 and -82192. Proc. NIPR Symp. Antart. Meteor. 1st, $122-134$.

Koeberl C. Warren P. H., Lindstrom M. M. SPettel B. and FukUoka T. (1989) Preliminary examination of the Yamato-86032 lunar meteoritc: II. Major and trace element chemistry. Proc. NIPR Symp. Antarct Meteor. 2nd, 15-24

KofBerl. C., KURAT G. AND BrandstÄtTER F. (1990) Lunar meteorite Yamato-86032: Mineralogical, petrological, and geochemical studies. Proc. NIPR Symp. Antarct. Meteor. 3rd, 3-18.

Korotev R. L. (1981) Compositional trends in Apollo 16 soils. Proc. Lunar Planet. Sci. Conf. 12th, 577-605.

Korotev R. L. (1987a) The nature of the meteoritic components of Apollo 16 soil, as inferred from correlations of iron, cobalt, iridium, and gold with nickel Proc Lunar Planet Sci. Conf 17th, E447-E461.

KOROTEV R L. (1987b) Mixing levels, the Apennine Front soil component, and compositional trends in the Apollo 15 soils. Proc Lunar Planet. Sci Conf 17th, E411-E431.

KoRoteV R. L. (1991) Geochemical stratigraphy of two regolith cores from the Central Highlands of the Moon. Proc. Lunar Planet. Sci. Conf. 21st 229-289

KOROTEV R. L. (1994) Compositional variation in Apollo 16 impact-melt breccias and inferences for the geology and bombardment history of the Central Highlands of the Moon. Geochim. Cosmochim. Acta 58. 39313969.

KOROTEV R. L. (1995) Geochemical stratigraphy of the Apollo 15, Apennine Front core (15007/8) (abstract). Lunar Planet. Sci. 26, 783-784.

KOROTEV R. L. (1996a) The composition of the prebasin crust in the Central I Highlands of the Moon (abstract). Lunar Planet Sci. 27, 689 690

KOROTEV R. L. (1996) On the relationship between the Apollo 16 ancient regolith breccias and feldspathic fragmental breccias, and the composition of the prebasin crust in the Central Highlands of the Moon. Meteorit Planet. Sci 31, 403-412.

KoroteV R. I. AND KREMSER D. T. (1992) Compositional variations in Apollo 17 soils and their relationship to the geology of the TaurusLittrow site. Proc. Lunar Planet. Sci. Conf. 22nd, 275-301.

KOROTEV R. L., HASKIN L. A. AND LINDSTROM M. M. (1980) A synthesis of lunar highlands compositional data. Proc. Lunar Plamet. Sci. Conf. 11 th, 395-429.

KOROTEV R. L., LINDSTROM M. M., LINDSTROM D. J. AND HASKIN L. A (1983) Antarctic meteorite ALIIA81005-Not just another lunar anorthositic norite. Geophys. Res. Lett. 10, 829-832.

LINDSTROM M. M. AND LINDSTROM D. J (1986) Lunar granulites and their precursor anorthositic norites of the early lunar crust. Proc. Lunar Planet. Sci. Conf. 16th. D263-276.

IINDSTROM M. M., LINDSTROM D. J., KOROTEV R. I. AND HASKIN L. A. (1986) Lunar meteotite Yamato-791197: A polymict anorthositic norite 
from the lunar highlands. Mem. Natl Inst. Polar Res., Spec. Issue $\mathbf{4 1}$ $58-75$

L.INDSTROM M. M., MITTLIFHIIIDT D. W. MARTINEZ R. R., LIPSCHUTZ M J. ANI WANG M.-S. (1991) Geochemistry of Yamato-82192, -86032 and -793274 lunar meteorites. Proc. NIPR Symp. Antarct. Mereor. 4th, $12-32$.

I.inidstrom M. M., Mittlefehldt D. W., Morris R. V., Martinez R. R. AND WENTWORTH S. J. (1995) QUE93069, a more mature regolith breccia for the Apollo 25 th anniversary (abstract). Lunar Planet. Sci. 26, 849-850

LUCliY P. G., TAYloR G. J. AND Malaret E. (1995) Abundance and distribution of iron on the Moon. Science 268, 1150-1153.

MC(itE J. J. (1993) Lunar ferroan anorthosites: Mineralogy, compositional variations, and petrogenesis. $J$. Geophys. Res. 98,9080-9105.

MCKAy D. S., FRULAND R. M. AND HEIKEN G. H. (1974) Grain size and the evolution of lunar soil. Proc. Lunar Planet. Sci. Conf. 5th, 887-906.

MORRIS R. V., SEE T. II. AND I HORZ F. (1986) Composition of the Cayley Formation at Apollo 16 as inferred from impact melt splashes. Proc. Lunar Planet. Sci Conf. 17th. E21-E42.

MORRIS R. V., KOROTEV R. L. AND L AUER H. V., JR. (1989) Maturity and geochemistry of the Van Serg crater core (79001/2) with implications for micrometeorite composition. Proc. Lunar Planet. Sci. Conf. 19th. $269-284$.

NFal C. R., TAYLOR L. A., I.IU Y. AND SCHMITT R. A.(1991) Paired lunar meteorites MAC88104 and MAC88105: A new "FAN" of lunar petrology. Geochim. Cosmochim Acta 55, 3037-3049.

Nishizumi K., Caffee M. W., Finktil. R. C. and Reedy R. C. (1995) Exposure history of lunar meteorite QUE93069 (abstract). Lunar Planet. Sci. 26, 1051-1052.

Ostertag R., Stoffler D., Bischoff A., Palme H., Schultz L., Spettel B., WEBER II., WECKWERTH (i. AND WANKE H. (1986) Lunar meteorite Yamato-791197: Petrography, shock history and chemical composition. M'm. Natl Inst. Polar Res., Spec. Issue 41, 17-44.

PALME H., SPETTFL B., WEG KWERTH (3. AND WANkE II. (1983) Antarctic meteorite ALIIA 81005 , a piece from the ancient lunar crust. Geophys. Res Lett 10,817-820.

Palme II., Spettel B., Jochum K. P., Driabus G., Weber h., WeckWERTH G., WANKE H., BISCHOFF A. AND STOFFLER D. (1991) Lunar highland meteorites and the composition of the lunar crust. Geochim. Cosmochim Acta 55, 3105-3122.

PAPIKE J. J. SIMONS. B. ANI) TAYLOR L. A. (1991) Ch. 5. Lunar Minerals. In L.unar Sourcebook (eds. (i. Heiken, D. Vaniman and B. M. French), pp. 121-181. Cambridge Univ. Press, Cambridge, United Kingdom.

Pietiers C. M., Hawke B. R., Gaffey M. and Mo Fadden L. A (1983) Possible lunar source areas of meteorite ALHA81005: Geochemical remote sensing information. Geophys. Res. Lett. 10, 813-816.

SCLAR C. B. AND BAUIR J. F. (1975) Shock-induced subsolidus reductiondecomposition of orthopyroxene and shock-induced melting in norite 78235. Proc. Lumar Planet. Sci. Conf. 6th. 799-820.

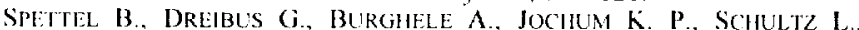
WeBER H. W., WLOTZKA I. AND WANKE II. (1995) Chemistry, petrology, and noble gases of lunar highland meteorite Qucen Alexandra Range 93069 (abstract). Meteoritics 30, 581-582.

STOFFIER D., BISCIOFF A., BORCHARDT R., BURGHELE $A$., DeUTSCH $A$., Jessberger E. K., Osthrtag R, Palme i., Spettea. B., Reimold W.
U., WACHER K. AND WANKE H. (1985) Composition and evolution of the lunar crust in the Descartes hightands, Apollo 16. Proc. Lunar Planet. Sci. Conf. 15th, C449-C506.

SWINDLE T. D., BURk!.AND M. K. ANd GRier J. A. (1995) Noble gases in the lunar meteorites Calcalong Creek and Queen Alcxandra Rangc 93069 (abstract). Meteoritics 30, 584-585.

TAKEDA H., MORI H. AND TAGAI T. (1987) Mineralogy of lunar meteorites, Yamato-82192 and -82193 with reference to breccias in a breccia Mem. Natl. Inst. Polar Res., Spec. Issue 46, 43-55.

Takeda H., Kojma H., Nishio F., Yanai K., Lindstrom M.M. and Yamato Lunar METEORITE CONSORTIUM Group (1989) Preliminary report on the Yamato-86032 lunar meteorite: I. Recovery, sample descriptions, mineralogy and petrography. Proc. NIPR Symp. Antarct. Meteor. 2nd, 3-14.

Takeda H, MiYamoto M., Mori II., Wentworth S. J. ANI) M(Kay D. S (1990) Mineralogical comparison of the Y86032-type lunar meteorites to feldspathic fragmental breccia 67016. Proc. Lunar Plamet. Sci. Conf. 20th, 91-100.

Taylor G. J., Warren P., Ryder G., Delano J., Pittirs C. and LOFGREN G. (1991) Ch. 6. Lunar Rocks. In Lunar Sourcebook (eds. G. lleiken, D. Vaniman and B. M. French), pp. 183-284. Cambridge Univ. Press, Cambridge, United Kingdom.

TAYLOR S. R. (1975) Lunar Science: A Post-Apollo View. Pergamon, New York, New York. $372 \mathrm{pp}$.

TAYIOR S. R. (1982) Planefary Science: A Lunar Perspective. Lunar and Planetary Institute, Houston, Texas. $481 \mathrm{pp}$.

THALMANN CH. AND EUGSTER O (1995) Lunar meteorite Queen Alexandra Range 93069: History derived from cosmic-ray-produced and trapped noble gases (abstract). Meteoritics 30, 585-586.

TREiman A. II. AND DRAKE M. J. (1983) Origin of lunar metcorite Al.HA81005: Clues from the presence of terrae clasts and a very lowtitanium mare basalt clast. (jeophys. Res. Lett. 10,783-786.

WARREN P. H. (1989) KREEP: Major-element diversity, trace-element uniformity (almost). In Workshop on Moon in Transition. Apollo 14. KREEP, and Evolved Lunar Rocks (eds. (i. J. Taylor and P. H. Warren) pp. 149-153. LPI Tech. Rpt. 89-03. Lunar and Planetary Institute, Houston. Texas.

WARREN P. H. (1994) l.unar and Martian meteorite delivery systems. Icarus 111, 338-363.

WARREN P.H. AND KaLLEMEYN G.W. (1986) Geochemistry of lunar meteorite Yamato-791197: Comparison with ALHA81005 and other lunar samples. Mem. Natl. Inst. Polar Res. Spec. Issue 41, 3-16.

WARREN P. H. AND KALI.EMEYN G. W. (1991) Geochemical investigations of five lunar meteorites: Implications for the composition, origin and cvolution of the lunar crust. Proc. NIPR Symp. Antarct. Meteor. 4th, $91-117$.

WARREN P. H. AND KALLEMEYN G. W. (1993) Geochemical investigations of two lunar mare meteorites: Yamato-793169 and Asuka-881757. Proc. NIPR Symp. Antarct. Meteor. 6th, 35-57.

WARREN P. H. AND KALLEMEYN $G$. W. (1995) QUE93069: A lunar meteorite rich in IIASP glasses (abstract). Lunar Planet. Sci. 26, 1465-1466.

WASSON J. T., BOYNTON W. V., CHOU C.-L. AND BAEDECKER P. A. (1975) Compositional evidence regarding the intlux of interplanctary materials onto the lunar surface. The Moon 13, 121-141. 